\title{
BDNF as a Promising Therapeutic Agent in Parkinson's Disease
}

\author{
Ewelina Palasz $^{1}$, Adrianna Wysocka ${ }^{2}$ (D), Anna Gasiorowska ${ }^{1}$, Malgorzata Chalimoniuk ${ }^{3}(\mathbb{D}$, \\ Wiktor Niewiadomski ${ }^{1}$ and Grazyna Niewiadomska ${ }^{2, *}$ \\ 1 Mossakowski Medical Research Centre Polish Academy of Sciences, 02-106 Warsaw, Poland; \\ epalasz@imdik.pan.pl (E.P.); anigas@wp.pl (A.G.); wniewiadomski@imdik.pan.pl (W.N.) \\ 2 Nencki Institute of Experimental Biology Polish Academy of Sciences, 02-093 Warsaw, Poland; \\ a.wysocka@nencki.edu.pl \\ 3 Faculty in Biala Podlaska, Jozef Pilsudski University of Physical Education in Warsaw, \\ 21-500 Warszawa, Poland; malgorzata.chalimoniuk@awf-bp.edu.pl \\ * Correspondence: g.niewiadomska@nencki.edu.pl; Tel.: +48-225892409
}

Received: 19 December 2019; Accepted: 6 February 2020; Published: 10 February 2020

Abstract: Brain-derived neurotrophic factor (BDNF) promotes neuroprotection and neuroregeneration. In animal models of Parkinson's disease (PD), BDNF enhances the survival of dopaminergic neurons, improves dopaminergic neurotransmission and motor performance. Pharmacological therapies of PD are symptom-targeting, and their effectiveness decreases with the progression of the disease; therefore, new therapeutical approaches are needed. Since, in both PD patients and animal PD models, decreased level of BDNF was found in the nigrostriatal pathway, it has been hypothesized that BDNF may serve as a therapeutic agent. Direct delivery of exogenous BDNF into the patient's brain did not relieve the symptoms of disease, nor did attempts to enhance BDNF expression with gene therapy. Physical training was neuroprotective in animal models of PD. This effect is mediated, at least partly, by BDNF. Animal studies revealed that physical activity increases BDNF and tropomyosin receptor kinase $B$ (TrkB) expression, leading to inhibition of neurodegeneration through induction of transcription factors and expression of genes related to neuronal proliferation, survival, and inflammatory response. This review focuses on the evidence that increasing BDNF level due to gene modulation or physical exercise has a neuroprotective effect and could be considered as adjunctive therapy in PD.

Keywords: brain-derived neurotrophic factor; neurodegeneration; Parkinson's disease; physical exercise; neuroprotection; PD therapy

\section{Introduction}

Brain-derived neurotrophic factor (BDNF) belongs to neurotrophins (NTs) - a family of proteins that support the function of the central nervous system (CNS). Neurotrophins are synthesized mainly in CNS [1], but also in the non-neuronal peripheral cells such as $\mathrm{T}$ and B lymphocytes, monocytes [2], vascular endothelial [3], and smooth [4] and skeletal muscle cells [5]. BDNF expression was confirmed in the hippocampus, frontal cortex, midbrain, amygdala, hypothalamus, striatum (ST), pons, and medulla oblongata [6,7]. BDNF plays a key role in the development of the nervous system by affecting cell differentiation, neuronal development, growth and survival, neurogenesis, synaptogenesis, and synaptic plasticity [7-10]. Furthermore, it was shown that neurodegenerative and neuropsychiatric diseases may be partially caused by defects in synaptic plasticity associated with the insufficient neuronal supply of BDNF and other neurotrophic factors [11-13]. For this reason, there is a need to search for new strategies to increase the BDNF level as a tool in prevention and therapy of neurological diseases. 


\section{Brain-Derived Neurotrophic Factor-Regulation of Synthesis, Activation of Specific Receptors, Location and Function in the Nervous System}

The broad spectrum of processes controlled by BDNF can be explained by the specificity of its multistage synthesis, progressing through several intermediate biologically active isoforms that bind to different types of receptors, and can trigger several signaling pathways [14].

The $B d n f$ gene is located on chromosome 11 and contains 9 promoters that can initiate transcription of 24 transcripts, each containing an alternative $5^{\prime}$ noncoding exon spliced to a $3^{\prime}$ coding exon that comprises the entire open reading frame for the BDNF protein [15]. The pre-proBDNF precursor is synthesized in the endoplasmic reticulum and then transported to the Golgi apparatus, where the preregion sequence is cleaved to produce the proBDNF isoform. Then, proBDNF may be converted into mature BDNF (mBDNF) in the trans-Golgi network by the subtilisin-kexin family of endoproteases such as furin or in intracellular vesicles by convertases $[14,16]$. Extracellular formation of mBDNF is catalyzed by plasmin and matrix metalloproteases. Studies have shown that proBDNF can be also cleaved to release segment longer than $\mathrm{mBDNF}$, which is called truncated BDNF and whose physiological function is largely unknown [15]. The balance between proBDNF and mBDNF depends on the stage of brain development and on the brain region. A higher level of proBDNF is observed during brain development, while mBDNF exerts neuroprotective activity and promotes synaptic plasticity during adulthood [17-21].

Recently, it has been reported that synthesis of BDNF may be affected by 20-22 nucleotide noncoding RNA molecules called microRNAs (miRNAs). MiRNAs bind to 3' untranslated regions ( $\left.3^{\prime} \mathrm{UTR}\right)$, of target mRNAs and promote their degradation or suppress their translation into proteins, thereby silencing gene expression [22-24]. For example, in vitro studies have shown that miRNA-26a and miRNA-26b target 3'UTR of BDNF mRNA in HeLa cells [25], while miRNA-140 and miRNA-211 target the 3'UTR of BDNF mRNA in human astrocyte cultures [26,27]. Furthermore, elevated brain level of miR-206 was reported in the mouse model of Alzheimer's disease (AD), whereas its reduction enhanced the synthesis of BDNF and improved memory function [28]. A study performed by Li et al. [29] has shown a diminished level of BDNF and an elevated level of miR-132 and miR-182 in the serum of patients with depression compared with healthy controls, which suggest that these miRNAs inhibit BDNF synthesis. Interestingly, Mellios et al. [22] have reported an increased level of several different miRNAs in human prefrontal cortical tissue that corresponded directly with subjects' age and inversely with a decreased level of BDNF. In turn, a recent study has demonstrated that inhibition of miR-103a can block the activation of astrocytes in the hippocampus and reduce the pathological injury of neurons of epilepsy rats [30].

BDNF level in the peripheral tissues, brain, and blood may be also affected by gene polymorphism. BDNF gene polymorphism gives rise to a substitution of methionine for valine at position 66 (Val66Met) in proBDNF, causing a decreased dendritic distribution, reduced BDNF transport to secretory granules, and low activity-dependent secretion of BDNF [31,32]. An ethnicity-specific meta-analysis showed that Val66Met may increase susceptibility to PD in Europeans, but not in Asians, and increase the risk of suicidal behaviors in Asian and Caucasian populations [33].

ProBDNF and mBDNF exert their biological activity by binding to two types of cell surface receptors, the Trk tyrosine kinases and the p75 neurotrophin receptor (p75NTR) [34]. Interestingly, they often have an opposite effect on survival, differentiation, growth, and apoptosis of neurons; thus, the proBDNF/mBDNF balance is an important factor inf the regulation of many processes in CNS $[35,36]$. mBDNF binds with a high affinity to the TrkB receptor, while proBDNF has a greater affinity to the p75NTR, through its mature domain and to the sortilin receptor through the prodomain. The proBDNF/p75/sortilin complex leads to the activation of c-Jun N-terminal (JNK), Ras homolog gene family member A (RhoA), and nuclear factor kappa B (NF-kB) signaling pathways, which trigger neuronal apoptosis, neuronal growth cone development, and neuronal survival, respectively [14].

Upon mBDNF binding, the TrkB receptor is dimerized and autophosphorylated at tyrosine residues in its intracellular domain. Then, tyrosine residues (Tyr 515 and Tyr 816) located in the 
juxtamembrane region and in the carboxyl terminus of the receptor $[37,38]$ become phosphorylated, which leads to activation of Ras, phosphatidylinositol 3-kinase (PI3K), phospholipase C- $\gamma$ (PLC- $\gamma$ ), and their downstream effectors [39]. The downstream effectors include Ras stimulation of mitogen-activated protein kinase (MAPK) pathways, PI3K stimulation of protein kinase B (Akt), and PLC- $\gamma 1$-dependent generation of inositol trisphosphate (IP3) and diacylglycerol (DAG) that results in mobilization of $\mathrm{Ca}^{2+}$ stores and activation of $\mathrm{Ca}^{2+}$ and DAG-regulated protein kinases [37,40].

BDNF-TrkB signaling pathways regulate multiple events, such as dendritic growth, pine maturation and stabilization [41-43], development of synapses [44,45], learning- and memory-processes-dependent synaptic plasticity [40,46,47], apoptosis, and survival of neurons [48-51]. The intracellular signaling cascades and physiological function of BDNF are key to understanding the mechanisms underlying the neuroprotective properties of this neurotrophin, enabling proper cell functioning and survival (Figure 1).

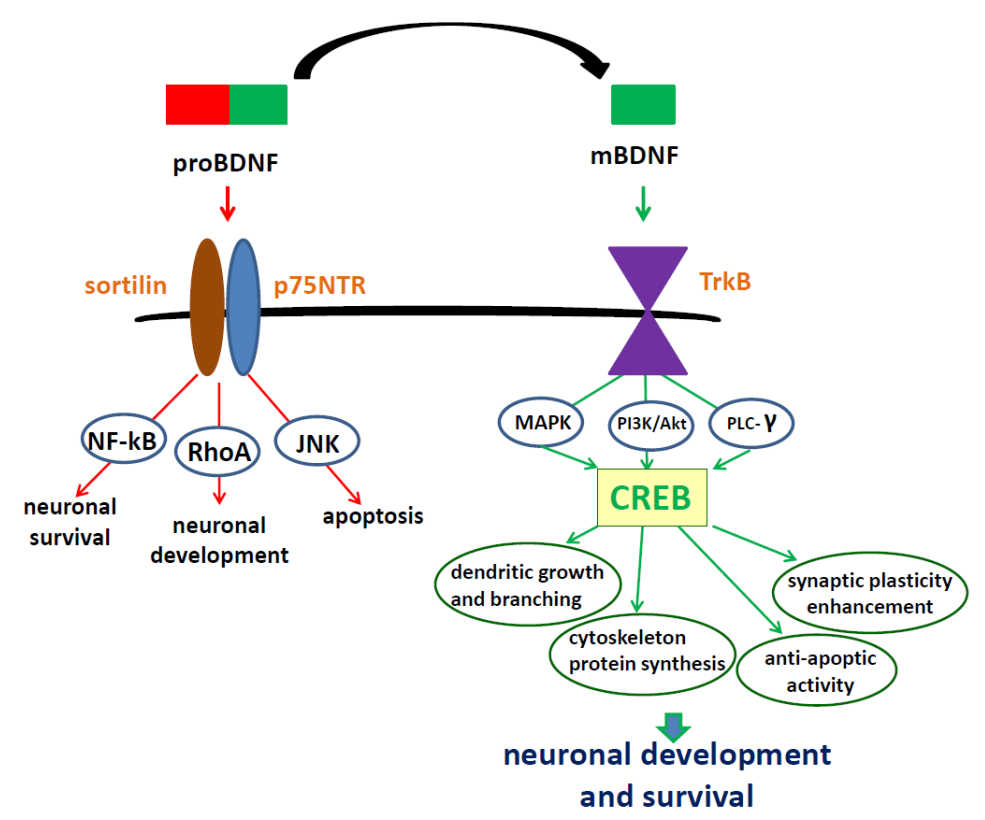

Figure 1. Signaling cascades activated by interaction of BDNF isoforms with two types of cell surface receptors, the $\mathrm{p} 75$ neurotrophin receptor and TrkB receptor. proBDNF has a greater affinity for the $\mathrm{p} 75$ receptor. The pro-BDNF/p75/sortilin complex leads to activation of JNK, RhoA, and NF-kB signaling pathways which promote processes such as apoptosis, neuronal growth cone development, and neuronal survival. The mBDNF/TrkB receptor complex triggers activation of three signaling pathways-MAPK, PI3K/Akt, and PLC- $\gamma$ - that, in turn, activate the transcription factor CREB and transcription of genes responsible for development and survival of neurons. proBDNF- precursor of brain-derived neurotrophic factor, $\mathrm{mBDNF}$ - mature brain-derived neurotrophic factor, TrkB-tropomyosin receptor kinase B, JNK—c-Jun N-terminal kinases, RhoA—Ras homolog gene family member, NF-kB-nuclear factor kappa B, MAPK-mitogen-activated protein kinase, PI3K-phosphatidyl inositol-3 kinase, PLC- $\gamma$ - phospholipase C- $\gamma$, CREB-cAMP response element-binding protein.

\section{Role of BDNF in Neurodegeneration and Neuroregeneration}

Neurotrophic factors have been extensively investigated in the context of neurodegenerative diseases. The alterations in the regulation of specific neurotrophic factors and their receptors seem to be involved in neurodegeneration. Neurotrophins prevent cell death and support neuronal proliferation and maturation, enhancing the growth and function of affected neurons in AD and PD [52,53]. In current therapies for $\mathrm{AD}$ and $\mathrm{PD}$ which focus on prevention of neurodegeneration, application of neurotrophic factors has emerged as one of the therapeutic approaches in early, middle and even late stages of these 
disorders. Even though studies in animal models are promising, their effectiveness in clinical studies remains unclear [53,54].

By activating the IP3K/Akt kinase pathway, neurotrophins inhibit processes that elicit cell death [55-57]. It was found that the decrease in expression of NTs, especially BDNF observed in the aging process and in neurodegenerative diseases, may contribute to degeneration and death of neurons [58]. A decrease in BDNF levels in the blood and brain was observed in patients with depression or suffering from PD and AD [59-62]. Decreased BDNF concentration in serum and brain is accompanied by an increase in degeneration of dopaminergic neurons in $\mathrm{PD}$, which leads to movement disorders, cognitive deficit, and mental disorders [63-66] and also correlates with memory impairment in $\mathrm{AD}[67,68]$. There are data indicating that a decrease in BDNF levels in PD may contribute to overexpression of alpha-synuclein (ASN) and inhibition of dopamine (DA) synthesis [69-71]. Moreover, it was reported that ASN overexpression downregulated BDNF transcription and impaired BDNF trafficking in neurons [53]. BDNF participates in the regulation of tyrosine hydroxylase (TH), which is also reduced in PD, consequently leading to motor disorders [72,73]. In addition, Ziebell et al. [74] have found that in patients with striatal dopaminergic neurodegeneration, serum BDNF levels decrease along with loss of the striatal dopamine transporter (DAT). Silencing the gene encoding BDNF in mice resulted in the loss of dopaminergic neurons, which confirms the role of BDNF in protecting neurons against injury and degeneration $[72,75,76]$. There are studies showing that glial cell-derived neurotrophic factor (GDNF) can also prevent the degeneration of dopaminergic neurons in PD [77,78].

The neuroprotective effect of BDNF is the result of activation of the TrkB/MAPK/ERK1/2/IP3K/Akt pathway, which leads to attenuation of apoptosis, glutamate, and nitric oxide (NO) neurotoxicity and cell damage caused by oxidative stress [79]. An increase in oxidative stress, glutamate neurotoxicity, NO production, and the process of apoptosis are observed in PD [80] and other neurological disorders [81,82].

A key role of BDNF in the deterioration of motor and cognitive abilities in PD may arise from experiments on animal models, where BDNF level was decreased due to genetic modification. The knockout of the $B d n f$ in midbrain-hindbrain in WNT-BDNF ${ }^{\mathrm{KO}}$ mice resulted in motor impairments (hind limb clutching and poor rotarod performance) [72]. In turn, 6-8-week-old $B d n f+/-$ mice showed worse performance in Morris Water Maze than control animals, whereas 10-month-old Bdnf $+/-$ animals did not learn at all, suggesting that the BDNF may alter learning abilities [83].

\section{BDNF as a Promising Compound in the Therapy of Parkinson's Disease}

The body of data suggesting a relation between the decline of BDNF level and progression of PD is growing steadily $[62,84-87]$. The fact that there is currently no cure for PD highlights the need to seek new therapeutic agents that will make the treatment of PD more effective. Given the properties of BDNF, its application for treatment of neurodegenerative diseases, including PD, seems promising.

\subsection{Upregulation of BDNF Signaling through Direct Injection and Gene Therapy}

\subsubsection{Study in PD Animal Models}

In the animal models of PD, BDNF brain content was augmented through direct injection of BDNF $[88,89]$, gene transduction by viral vectors [90-94], or delivery via nonviral carriers $[95,96]$ and also via secretion from genetically engineered cells [97-101]. The effects of BDNF treatment were studied in two research schemes in which BDNF was administered before and after the induction of PD.

In the vast majority of studies with BDNF administration before induction of parkinsonism, the research results revealed at least partial prevention of neuronal cell loss $[89,90,92,93,99,101]$. BDNF increased survival of Nissl- or neuronal-nuclei-stained neuronal cells [92,99,101] and dopaminergic neurons $[89,92,93,99]$ in substantia nigra (SN) and protected dopaminergic projections to ST [92,93]. Moreover, BDNF administration increased DA level in SN $[92,100]$ and ST $[88,92]$ and restored DA uptake in ST [101]. However, the reports are not consistent; some have shown no increase in neuronal 
survival when BDNF was applied before intoxication with 6-hydroxydopamine (6-OHDA) in PD animal model [90,91].

Similarly controversial results were obtained when induction of parkinsonism by 6-OHDA lesion was followed by BDNF treatment. There seemed to be no recovery of the dopaminergic neurons number in SN $[92,95,97,98]$. However, Kim et al. [92] demonstrated dopaminergic axon regrowth when the $B d n f$ gene was transduced 6 weeks after the axonal lesion. Moreover, BDNF treatment of brain slices from 1-methyl-4-phenyl-1,2,3,6-tetrahydropyridine (MPTP)-treated mice was able to restore the impaired synaptic plasticity [102]. In addition, Hernandez-Chan et al. [95] observed an increase in the striatal level of DA, while in SN there was no recovery of DA content. Therefore, it seems that even though BDNF does not induce neurogenesis, it exerts a positive influence on the remaining neurons. In contrast, Razgado-Hernandez et al. [96] noticed that the combined administration of agonist of D3 subtype of the dopamine receptor and gene-delivered BDNF are able to markedly rescue dopaminergic neurons in SN and dopaminergic projections to ST. Additionally, the treatment fully recovered the number of dopaminergic spines [96]. Furthermore, virus-derived BDNF upregulated dopamine D1 receptor-dependent cyclicAMP/protein kinase A (cAMP/PKA) signaling cascade [94], which was shown to alter impaired fear extinction in PD mice [103]. Interestingly, BDNF modulated also serotonergic system activity, which, together with dopaminergic and noradrenergic system, is involved in motor control. BDNF elevated serotonin (5-hydroxytryptamine, 5-HT) terminal sprouting in ST and globus pallidus measured as an increase in serotonin fibers density [94].

In the case of alternations in behavior, the studies on monkeys revealed significantly less severe symptoms of PD in animals treated with BDNF [89]. Moreover, Kim et al. [92] observed a decreased amphetamine-induced ipsiversive bias in rotational behavior associated with the protection of dopaminergic neurons [92]. Despite the lack of dopaminergic neuroprotection, Klein et al. [90] and Yoshimoto et al. [98] noticed a significant decline in amphetamine-induced ipsiversive rotational bias indicative of the restoration of DA neurotransmission on the injected side. In turn, Sun et al. [91] reported that combined treatment with BDNF and GDNF resulted in a greater reduction in the ipsiversive bias as compared to BDNF treatment.

It was also shown that the BDNF administration recovers spontaneous motor behavior in the rat model of PD [95]. Combined treatment with a D3 receptor agonist and BDNF in 6-OHDA lesioned rats led to the stabilization of gait parameters, accelerated recovery of motor coordination and balance, and full recovery from muscle rigidity [96]. Contrastingly, Lucidy-Philipi et al. [97] reported no recovery of the rotational behavior in BDNF-treated parkinsonian animals.

In summary, BDNF treatment in animal models seemed to enhance dopaminergic neurons survival when administered before induction of PD or at least caused partial recovery of dopaminergic transmission despite lack of neurogenesis (Figure 2).
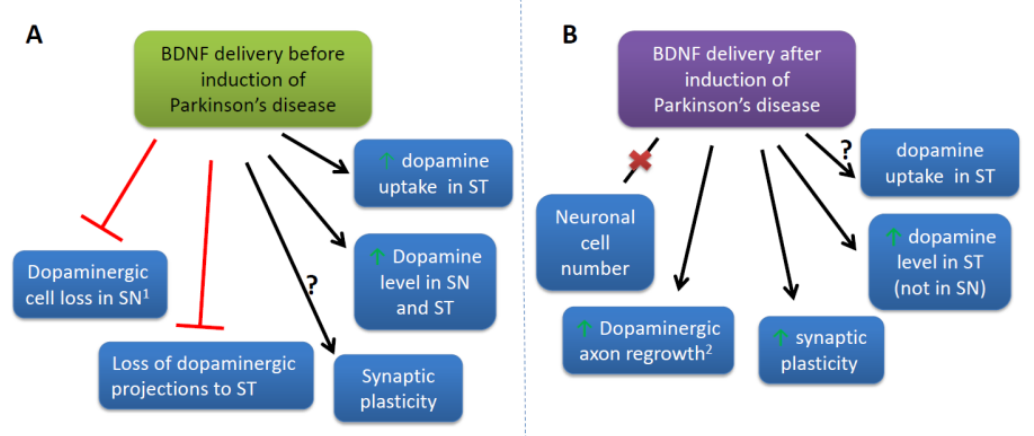

Figure 2. Summary of the major effects of BDNF delivery through direct injection and gene therapy before and after the induction of Parkinson's disease (PD) in animal models. (A) BDNF signaling upregulation before the induction of PD prevented dopaminergic cell loss in $\mathrm{SN}$ and the loss of 
dopaminergic projections to ST. BDNF stimulation elevated the DA level in SN and ST, and DA uptake in ST. To the best of our knowledge, studies concentrating directly on synaptic plasticity were not conducted. (B) BDNF delivery after induction of PD did not alter the number of dopaminergic neurons; however, it induced dopaminergic axon regrowth, increased synaptic plasticity, and elevated the DA level in ST, but not in SN. To our knowledge, DA uptake was not studied in this BDNF administration paradigm. Exceptions to the rules: ${ }^{1}$ Lack of neuronal cells preservation by BDNF treatment before PD induction [90,91]. ${ }^{2}$ Lack of effect on TH+ fibers in ST by BDNF treatment after PD induction [97,98]. BDNF-brain-derived neurotrophic factor, DA—dopamine, PD—Parkinson's disease, SN—substantia nigra, ST-striatum.

\subsubsection{Study in Humans}

Neurotrophins are challenging candidates for delivery into CNS due to the short in vivo half-life, poor bioavailability, and marginal permeability through the blood-brain-barrier (BBB). Furthermore, an important issue regarding chronic neurodegenerative disorders is the duration of treatment, which may last for years [104].

The first clinical trials that investigated the effect of BDNF administration in neurodegenerative diseases were performed in patients with amyotrophic lateral sclerosis (ALS) $[105,106]$. A study with subcutaneous administration of recombinant methionyl human BDNF (r-metHuBDNF) did not demonstrate a statistically significant effect of BDNF on the survival of these patients and did not replicate the beneficial effect of BDNF obtained in I and II phase of the study [105]. The purpose of the subsequent study was to determine the conditions for direct delivery of r-metHuBDNF to the cerebrospinal fluid (CSF) by a lumbar intrathecal catheter. Twenty-five patients with probable or definite ALS were treated with either r-metHuBDNF $(25,60,150,400$, or $1000 \mathrm{mg} /$ day) or placebo in a 12-week, randomized, double-blinded, sequential, dose-escalation study. This clinical trial showed that BDNF treatment with doses of $150 \mathrm{mg} /$ day was well tolerated and provided BDNF concentration in CSF that could be neuroprotective, but the number of patients included in the study was too small to make a conclusion about the efficacy of the treatment [106]. Clinical trials using NTs in the treatment of PD are rather limited to GDNF administration instead of BDNF. Some of them report the direct, beneficial, but transient effect of GDNF on DA function [107,108], and others show no effect of GDNF treatment on PD progression [109,110] and many side effects after its administration [110].

The fact that clinical trials have met with little success may be explained taking into account that successful delivery of therapeutic molecules should evade (i) rapid protein elimination from the cerebral circulation owing to enzymatic degradation, (ii) capture by the reticuloendothelial system, (iii) macromolecular accumulation in nontargeted tissues, and (iv) undesired immune responses [111]. Furthermore, currently, it is not possible to ensure that BDNF acts on precise target regions without affecting the function of neighboring areas [112].

Gene therapy is a strategy for enhancing BDNF expression in CNS. The choice of vector determines the technique used for its delivery. When a vector is peripherally administered, it must be able to cross the BBB with acceptable tissue specificity [113]. The most often used viral vectors infect the host cells, deliver a new gene, and lead to biosynthesis of a particular functional protein [114,115]. Theoretically, in vivo gene delivery can meet the requirements for safe and effective growth factor delivery to the brain and circumvent delivery to the brain with minimal (or no) spreading to nontargeted regions and reduced likelihood of protein instability [104]. Animal research on gene therapy additionally demonstrates that viral vectors successfully transduced neurons and provided the durable expression of BDNF [116-119].

To date, no clinical research on BDNF gene therapy has been performed. Thus, it is unknown whether the efficacy of neurotrophic factors gene therapy can be achieved. Current gene therapy trials in PD are focused on adenosine $\mathrm{A}_{2 \mathrm{~A}}$ antagonists [120], glutamic acid decarboxylase [120], GDNF [120,121], aromatic L-amino acid decarboxylase [120,122], and neurturin [123,124]. Out of these several approaches, only adenosine A2A antagonists show promising results in the management of 
motor complications in advanced stages of PD. A credible explanation for the low effectiveness of this approach may lie in the fact that dopaminergic neurons are dying or have already died [113].

\subsection{Stimulation of Endogenous BDNF Level by Physical Effort}

\subsubsection{Study in PD Animal Models}

BDNF production was shown to be stimulated by both voluntary [75] and forced physical activity [125-133]. BDNF upregulation was observed in midbrain [125], SN [126,128,129], ST [127,129,131,133], hippocampus [133], and cortex [132,133]. Tuon et al. [131] reported an attenuated decline of proBDNF content in 6-OHDA-induced PD rats trained for 60 days before lesion. In our study, we also noted a higher BDNF and GDNF immunostaining intensity in nigrostriatal areas of MPTP-treated mice which started treadmill training before (preceding training) and after (follow-up training) intoxication, as compared to control groups both sedentary and exercised [125]. Similarly, enzyme-linked immunosorbent assay showed a significant increase in BDNF in both MPTP preceding training and follow-up training groups as compared to both controls and MPTP sedentary group in the midbrain including SN. In ST, training increased BDNF concentration in both MPTP groups of trained animals and the control trained group as compared to sedentary control and MPTP animals.

BDNF brain level increase due to exercise was accompanied by several other effects. In animal models of PD, exercise was able to increase the number of TH-ir neurons in SN [125-130,134], the TH protein level in SN [126,128] and ST [128,134], and TH-ir fiber intensity in ST [127,128]. Physical activity also led to a normalization of the DA content in SN and/or ST $[75,126,129,130,132,133]$ and of 3,4-dihydroxyphenylacetic acid (DOPAC) level in ST [129,133], to a slight increase in the homovanillic acid (HVA) content in ST [133] and an elevation in the DAT level in ST [126,133]. HVA and DOPAC are DA metabolites, whereas DAT is responsible for DA reuptake from synapses. All these substances are the markers of the dopaminergic system and drop in the course of PD [135-137]. Furthermore, our study revealed a recovery of the intensity of vesicular monoamine transporter 2 (VMAT2) immunostaining in SN in exercised MPTP mice, indicative of the increase in the number of dopaminergic neurons [125].

In another study, it was shown that exercise increased TrkB content in SN [129]; however, in yet another study, TrkB content was significantly decreased in ST even below the level in the sedentary PD mice [131]. The authors suggest that the decreased TrkB level may be related to changes in synaptic plasticity [131]. In the case of the hippocampus, Tuon et al. [131] noticed a significant restoration of the relative TrkB content in 6-OHDA mice after 60 days of treadmill running. An injection of K252a, an inhibitor of the BDNF receptor, was able to obliterate the protective effect of exercise on dopaminergic neuron number in SN [128,129] and prevent the rise of TH protein level in SN and ST [128]. It seemed that the BDNF-TrkB pathway upregulation by exercise shielded the dopaminergic neurons in SN from lipopolysaccharide-induced degeneration [129] and 6-OHDA lesion in the animal model of PD [128].

Moreover, in MPTP mice with 18 weeks of pretraining, Lau et al. [126] showed protection of mitochondrial integrity and respiratory function in ST as compared to sedentary MPTP mice. In addition, da Costa group [133] also observed the drop in oxidative stress, which was measured as nitrite content and lipid peroxidation level.

The active glycogen synthase kinase 3 beta (GSK-3 $\beta$ ) was shown to mediate the MPTP- and 6-OHDA-induced neuronal cell death [138-141]. Choe et al. [134] observed deactivation of glycogen synthase kinase 3 beta (GSK-3 $\beta$ ) by its phosphorylation in both the lesioned and control side in 6-OHDA-induced rats, which trained for 16 days on the treadmill before lesion. It is possible that the GSK-3 $\beta$ deactivation may be caused by BDNF. Binding of BDNF to TrkB receptor leads to deactivation of GSK-3 $\beta$ by its phosphorylation, which in turn promotes cell survival [142].

Gerecke et al. [143] reported that heterozygous deletion of the BDNF gene ( $B d n f+/-$ mice) led to a lack of exercise-induced dopaminergic neuroprotection. Moreover, trained $B d n f+/-$ animals showed changes in protein expression related to energy metabolism, cytoskeleton, glycolysis, amino acid transport, synthesis and metabolism, and smaller changes in cytoplasmic signaling molecules 
and regulatory factors. Therefore, it seems that biallelic expression of BDNF is indispensable for the protective effect of exercise.

In addition, it was shown that, in animal models of $\mathrm{PD}$, training is able to improve motor performance, namely movement and balance on a balance beam [126] and motor memory in rotarod test $[129,133]$. Moreover, physical exercise increased spontaneous locomotor activity and subthreshold L-DOPA-induced activity [133] and decreased depressive-like behavior, measured as immobility, in open field test [131]. Furthermore, physical training decreased contralateral bias in cylinder test [127] and ipsilateral rotations in amphetamine-induced rotational test $[127,134]$ and reduced rotational asymmetry in apomorphine-induced rotational test $[128,131,133]$. Additionally, the use of BDNF receptor inhibitor K252a reversed the protective effect of exercise on rotational bias [128].

The aforementioned results from animal models of PD may indicate the key role of BDNF in exercise-driven neuroprotection (Figure 3). It seems that blocking BDNF signaling by inhibition of the TrkB receptor revokes the beneficial effects of physical exertion.

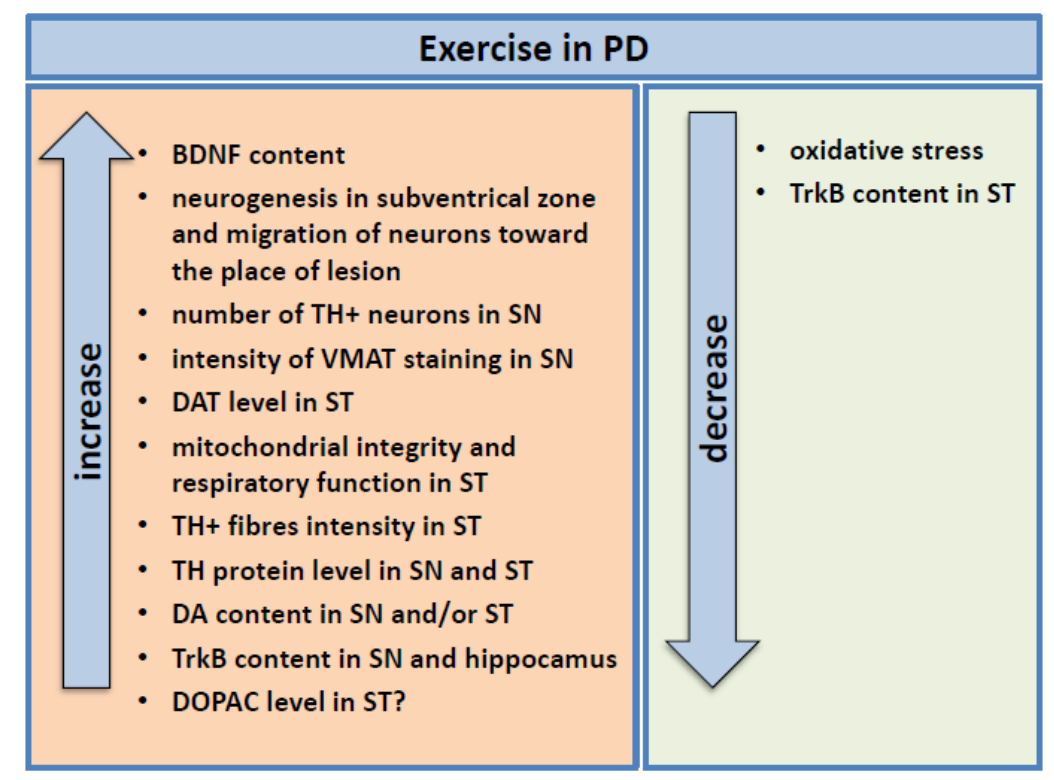

Figure 3. The molecular and physiological changes caused by exercise in animal models of Parkison's disease. Physical effort led to an increase in BDNF level, TH-ir cell number and TH protein content in SN, $\mathrm{TH}$-ir fibers intensity in ST, and DA content in SN and/or ST. The results from DOPAC content analysis in the brain were contradictory. Training also increased the level of TrkB in SN and hippocampus, but not in ST. In addition, exercise increased the DAT level in ST, VMAT staining intensity in SN. Physical activity was able to maintain mitochondrial integrity and respiratory function in ST, elevate neurogenesis in subventrical zone and migration of neurons toward the place of lesion, and decrease oxidative stress. BDNF-brain-derived neurotrophic factor, TrkB — tropomyosin receptor kinase B, SN—substantia nigra, ST—striatum, DA—dopamine, TH—tyrosine hydroxylase, DOPAC—3,4-Dihydroxyphenylacetic acid, DAT—dopamine active transporter, VMAT—vesicular monoamine transporter.

\subsubsection{Study in Humans}

The results of numerous studies show that regular long-term physical activity prevents the occurrence of neurodegenerative diseases in the elderly. Exercise improves mobility and increases muscle strength [144]. In addition, exercise therapy in the form of endurance training, resistance training, intensive mixed training, or high-intensity interval training (HIIT) resulted in a reduction of clinical symptoms in PD [145-152]. Long-term resistance and HIIT training reduced muscle tone and stiffness and had a positive effect on body balance in people with PD, osteoarthritis, and AD [153-156]. In addition, these forms of activity led to a reduction of movement disorders and a decrease in cognitive deficit in patients with PD [157]. Studies in healthy subjects have provided evidence that single aerobic 
exercise causes an increase in BDNF levels in plasma and serum [158,159]. It was also found that a few weeks or several months of physical training causes an increase in the initial BDNF level compared to the state before training, both in healthy subjects and PD patients [150,160-162]. This increase depends on the intensity and duration of the training process [163].

A systematic and critical literature search conducted by Knaepen et al. [160] demonstrated that acute aerobic, but not strength, exercise increased basal peripheral BDNF concentrations in healthy subjects, although the effect was transient. Also, a study performed by Schmolesky et al. [164] has indicated a significant increase in serum BDNF in adult human males after aerobic exercise, whereof a 40 min-long vigorous exercise ( $80 \%$ heart rate reserve) was most likely to produce a significant BDNF elevation. In most studies using acute protocols of training, BDNF concentration returned to baseline within 10-60 min postexercise, probably in response to greater tissue absorption [160]. The number of studies regarding the BDNF level in CSF in PD is limited, and their results are contradictory [165,166]. Interestingly, a meta-analysis performed by Hirsch et al. [167], in which results regarding 100 ambulatory patients with idiopathic PD (Hoehn/Yahr $\leq 3)$ were reviewed, found improvements in BDNF blood concentration levels after physical activity in all six analyzed studies.

\section{Possible Mechanisms Underlying the Protective Effect of BNDF Induced by Exercise}

The results obtained so far indicate that the increase in peripheral BDNF after aerobic or strength exercise is a temporary effect. It was also shown that a dose-response relationship exists between the intensity of the exercise and peripheral BDNF concentration [145]. The source of circulating BDNF in response to exercise is uncertain and widely discussed in the literature. It has been speculated that the exercise-induced increase in blood BDNF level originates partially from the contracting muscle cells. Although neurons in muscles produce BDNF as a result of exercise, it does not enter the bloodstream. In their studies, Matthews et al. [168] and Pratesi et al. [169] found an increase in BDNF mRNA expression in skeletal muscle in humans after physical effort and after electrical stimulation, but no release into the blood was observed. This concept is supported by data acquired both in vivo and with the use of a muscle cell culture model [168-170]. An increase in BDNF serum levels after exercise may be explained by the assumption that the brain is the main source of exercise-induced BDNF circulating in the blood [171-173]. Although the permeability of BBB for BDNF is very limited, there is evidence for a release of BDNF from the brain during exercise [174,175], which may reflect an association between peripheral and central BDNF levels and highlight plausibility of the hypothesis according to which the source of increased BDNF concentration due to exercise would be CNS. This concept is supported also by the fact that platelets do not produce BDNF. Platelets store circulating BDNF secreted by the brain, which they then can release back into the bloodstream [173].

In a period of about minutes to one hour after cessation of exercise, the level of peripheral BDNF concentration returns to the baseline [174,176-178]. Interestingly, after about 2-3 h since the end of the exercise, a significant drop below the baseline level of this neurotrophin has been observed [178]. The explanation of this phenomenon was attempted by Knaepen et al. [160]. They suggested that physical effort leads to a transient increase in BDNF synthesis in cells, from where its excess can be released into the bloodstream, resulting in an increase in peripheral BDNF levels. Then, BDNF can be absorbed by central and/or peripheral nerve tissues, in which it can induce neurotrophic and neuroprotective processes. This cycle, at least in part, explains the rapid return of BDNF concentration during postexercise restitution to values observed before exercise. Nevertheless, it seems that increase in BDNF is linearly associated with exercise intensity. Regular and systematic physical effort of moderate intensity may constantly raise BDNF concentration in the brain. Even though a single exercise causes a BDNF increase in the blood of patients with PD, it is short-lived and is not associated with an improvement in the neurological status of the patients. Studies using an animal model of parkinsonism have provided evidence that only the repetition of medium- or high-intensity physical exercise for several weeks or a continuous training process causes an increase in BDNF [179] and TrkB receptor levels $[131,180]$ in the brain regions responsible for motor activity in rats. 
Under the influence of the training process, increased BDNF expression in the hippocampus, cerebral cortex, ST, brainstem, and spinal cord was observed [131,174,179,181,182]. Animal studies have shown that long-term endurance training increased both TrkB receptor and TH expression in structures involved in extrapyramidal movement regulation, i.e., in the ST and midbrain $[128,129,179,183-185]$. As previously mentioned, the key element of neurotrophin-related neuroprotection is the IP3/Akt kinase pathway [186]. Data were also presented which indicate that physical activity may be neuroprotective by activating the PGC1a/FNDC5/BDNF/ERK1/2 pathway $[187,188]$. In addition, exercises increase transcription of peroxisome proliferator-activated receptor gamma coactivator 1-alpha (PGC1 $\alpha$ ), a protein that regulates mitochondrial biogenesis, which, in complex with estrogen-related receptor alpha, can stimulate the expression of myokine, the fibronectin type III domain-containing protein 5 (FNDC5) in the brain [187]. After cleavage of the signal peptide and cleavage of the site flanking the fibronectin domain, irisin glycopeptide is produced that triggers BDNF expression $[189,190]$. Thus, the increase of PGCla expression may in turn increase BDNF level.

BDNF binds to the TrkB receptor on the surface of the neurovascular unit and triggers a cascade of intracellular signals, transmitted primarily by MAPK/ERK1/2 and calcium and calmodulin-dependent protein kinase II (CaMKII), which are responsible for phosphorylation of cAMP-response element-binding protein (CREB, transcription factor, key for long-term neuronal plasticity). CREB binds to the appropriate sequence in the TH gene promoter, thereby increasing TH transcription [191,192]. Among the mechanisms related to exercise-dependent neuroplasticity, CREB is directly involved in regulating TH expression in PD [193,194]. Increased TH transcription plays a crucial role in exercise-dependent neuroplasticity. Application of physical exercises causes activation of CREB by different signal transducers, such as MAPKs, CaMK, and N-methyl-D-aspartate receptor (NMDA-R) in both the hippocampal and striatal plasticity $[195,196]$. An increase in TH enzyme activity, which is involved in the conversion of L-tyrosine to L-DOPA, from which DA is formed, favors the survival of dopaminergic neurons (Figure 4).

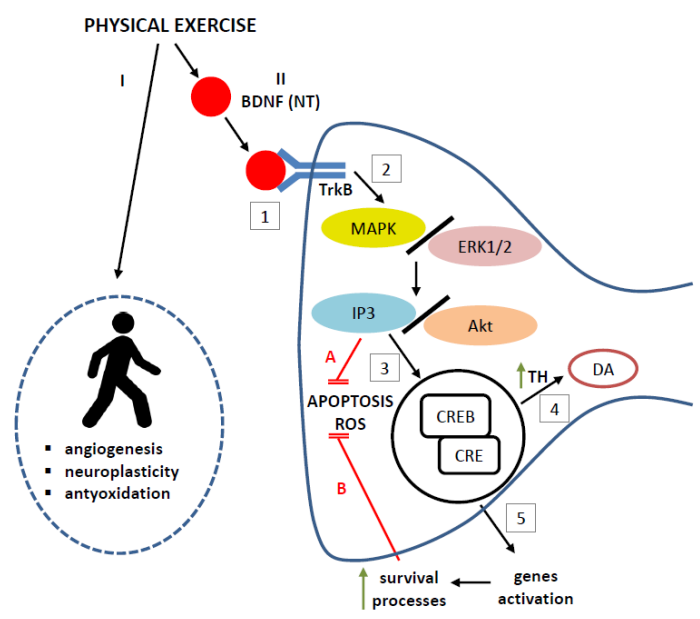

Figure 4. Systemic (I) and central nervous system (II) responses to physical exercise. (I) Physical exercise promotes angiogenesis and neuroplasticity, and anti-oxidation counteracts oxidative stress. (II) Physical exercise increases BDNF affinity to the TrkB receptor (1) enhancing a cascade of intracellular signals, including MAPK/ERK1/2-IP3/Akt pathway (2) that inhibits apoptosis and free radical release-ROS (A) on the one hand, and phosphorylation of transcription factor CREB on the other (3); the latter, by attaching to the CRE elements in the cell nucleus, increases the transcription of the tyrosine hydroxylase gene (4) responsible for conversion of tyrosine to L-DOPA, from which DA is formed, and transcription of genes (5) that promote the survival processes, thereby blocking apoptosis and inhibiting the formation of ROS (B). Akt-Akt enzyme, also known as protein kinase B, BDNF-brain-derived neutrophic factor, CREB - cyclicAMP-response element-binding protein, DA-dopamine, ERK-extracellular signal-regulated kinases, IP3 - inositol trisphosphate, L-DOPA—levodopa, MAPK—mitogen-activated protein kinase, ROS—reactive oxygen species, TrkB — tropomyosin receptor kinase B. 
Some authors suggest that physical effort mediates BDNF expression through monoaminergic activation, which entails increased adrenergic (noradrenaline) or serotoninergic (5-HT) neurotransmission. Indeed, prolonged physical activity causes an increase in NA and 5-HT activation associated with regulation of synapse plasticity and the signs of neuroprotection in the brain [197,198]. It has also been suggested that NA activation of $\beta$-adrenergic receptors may be necessary for exercise-induced BDNF regulation. The G-protein-coupled receptor and MAPK- and IP3K-mediated signaling pathways are indicated as those regulating the NA-dependent expression of the gene encoding BDNF [199,200].

There are also data that show that BDNF participates in the regulation of neuron metabolism, development, and proper functioning in cooperation with insulin-like growth factor-1 (IGF-1) [201]. Some authors indicate that the presence of both IGF-1 and BDNF is required for the viability and proper functioning of neuronal cells [186]. Physical exercise is known to increase the secretion of IGF-I and vascular endothelial growth factor (VEGF) which, together with BDNF, can improve memory by modulating synaptic plasticity, synapses, and neurotransmission in mature neurons [202].

Physical training protects DA neurons in the SNpc against inflammatory insult [179]. The beneficial effects of exercise are due to the activation of BDNF signaling pathway. Chronic exercise may reduce microglial reactivity and inflammation through regulation of multiple metabolic and transcriptional processes [203]. GSK-3 is a major regulator of the balance between the pro- and anti-inflammatory mediators in immune cells, including microglia [204]. GSK-3 stimulates the release of interleukin 1 beta (IL-1 $\beta$ ), interleukin 6 (IL-6), and tumor necrosis factor alpha in activated microglia and inhibits the release of anti-inflammatory cytokines like interleukin 10 (IL-10) [205]. Exercise may activate some extracellular signals that are known to inhibit GSK-3, including BDNF $[180,206]$. It is also possible that, as a result of a prolonged exercise, which increases the synthesis of trophic factors, there is no proinflammatory proliferation and activation of glial cells. This is because dopaminergic neurons protected by NTs do not degenerate and thus do not send signals mobilizing the proinflammatory response.

\section{Conclusions}

BDNF exerts well-documented neuroprotective and neurorestorative effects on dopaminergic neurons, which makes it a promising agent in PD therapy. However, neither direct delivery of exogenous BDNF into the patient's brain nor attempts to enhance BDNF expression with gene therapy turned out successful. Properly selected physical training may permanently increase BDNF level in blood and brain and, as evidenced in animal models, is to some extent able to protect neurons against neurotoxic assaults. Understanding the way training induces enhancement of BDNF expression and the mechanisms by which BDNF induces neuroprotection and neurorestoration may help design pharmacological treatment of PD and pave the way for novel PD therapies.

Author Contributions: The individual contributions: conceptualization, E.P. and G.N.; writing-original draft preparation, E.P., A.W., A.G., M.C., and W.N.; writing-review and editing, W.N. and G.N.; figures and figure captions, E.P., A.W., and A.G. All authors have read and agreed to the published version of the manuscript.

Funding: This work was funded by TauRx Therapeutics/WisTa Laboratories Ltd., Singapore and by statutory funds from the Nencki Institute of Experimental Biology and Mossakowski Medical Research Centre Polish Academy of Sciences.

Conflicts of Interest: The authors declare no conflict of interest.

\section{Abbreviations}

$\begin{array}{ll}\text { 5-HT } & \text { 5-hydroxytryptamine, serotonine } \\ \text { 6-OHDA } & \text { 6-hydroxydopamine } \\ \text { AAV2 } & \text { adeno-associated virus serotype 2 vector } \\ \text { AD } & \text { Alzheimer's disease }\end{array}$




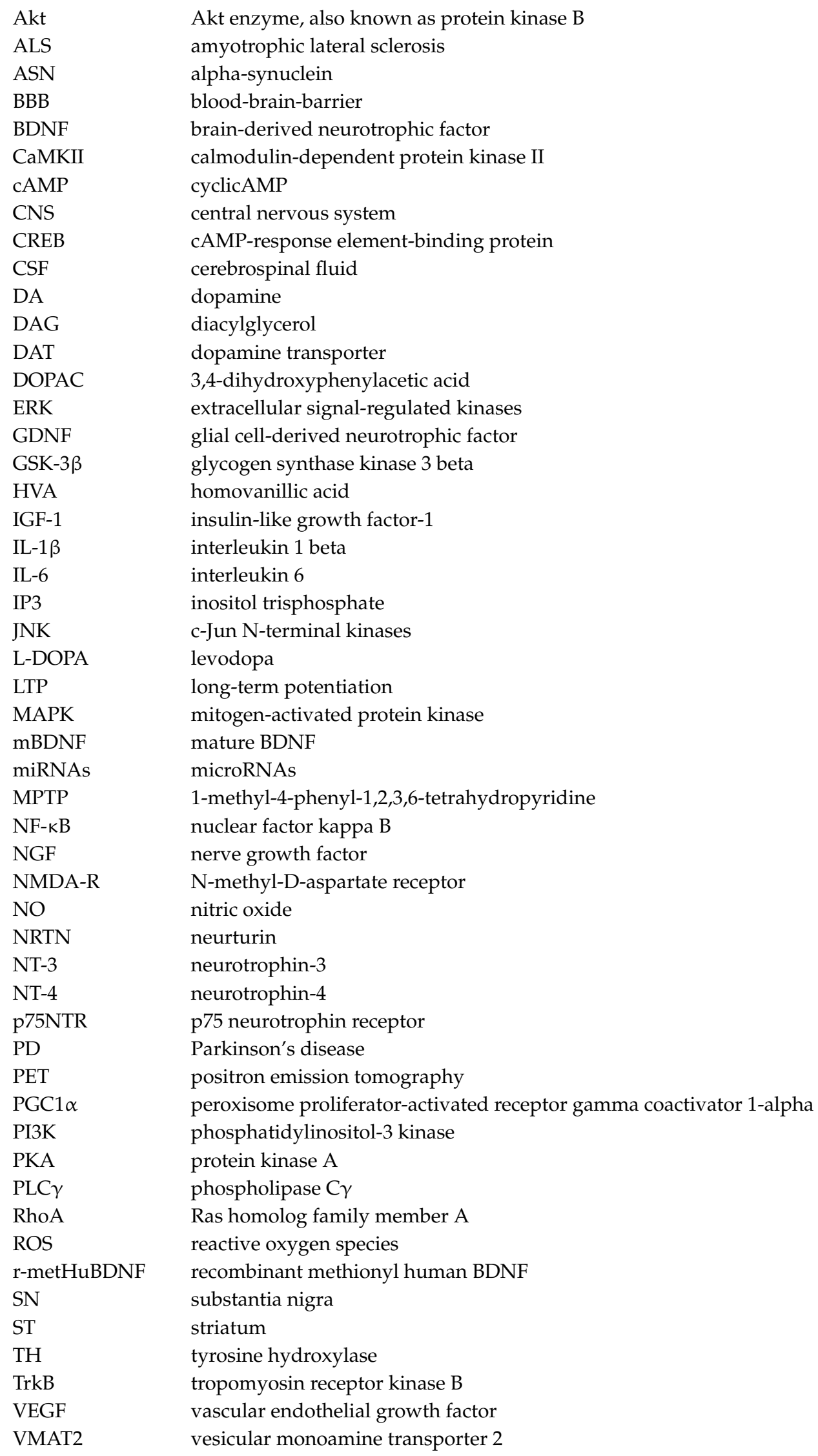




\section{References}

1. Conner, J.M.; Lauterborn, J.C.; Yan, Q.; Gall, C.M.; Varon, S. Distribution of brain-derived neurotrophic factor (BDNF) protein and mRNA in the normal adult rat CNS: Evidence for anterograde axonal transport. J. Neurosci. 1997, 17, 2295-2313. [CrossRef] [PubMed]

2. Kerschensteiner, M.; Gallmeier, E.; Behrens, L.; Leal, V.V.; Misgeld, T.; Klinkert, W.E.F.; Kolbeck, R.; Hoppe, E.; Oropeza-Wekerle, R.-L.; Bartke, I.; et al. Activated Human T Cells, B Cells, and Monocytes Produce Brain-derived Neurotrophic Factor In Vitro and in Inflammatory Brain Lesions: A Neuroprotective Role of Inflammation? J. Exp. Med. 1999, 189, 865-870. [CrossRef] [PubMed]

3. Nakahashi, T.; Fujimura, H.; Altar, C.A.; Li, J.; Kambayashi, J.I.; Tandon, N.N.; Sun, B. Vascular endothelial cells synthesize and secrete brain-derived neurotrophic factor. FEBS Lett. 2000, 470, 113-117. [CrossRef]

4. Donovan, M.J.; Miranda, R.C.; Kraemer, R.; McCaffrey, T.A.; Tessarollo, L.; Mahadeo, D.; Sharif, S.; Kaplan, D.R.; Tsoulfas, P.; Parada, L.; et al. Neurotrophin and neurotrophin receptors in vascular smooth muscle cells: Regulation of expression in response to injury. Am. J. Pathol. 1995, 147, 309-324.

5. Yarrow, J.F.; White, L.J.; McCoy, S.C.; Borst, S.E. Training augments resistance exercise induced elevation of circulating brain derived neurotrophic factor (BDNF). Neurosci. Lett. 2010, 479, 161-165. [CrossRef]

6. Murer, M.; Yan, Q.; Raisman-Vozari, R. Brain-derived neurotrophic factor in the control human brain, and in Alzheimer's disease and Parkinson's disease. Prog. Neurobiol. 2001, 63, 71-124. [CrossRef]

7. Tapia-Arancibia, L.; Aliaga, E.; Silhol, M.; Arancibia, S. New insights into brain BDNF function in normal aging and Alzheimer disease. Brain Res. Rev. 2008, 59, 201-220. [CrossRef]

8. Lee, J.; Duan, W.; Mattson, M.P. Evidence that brain-derived neurotrophic factor is required for basal neurogenesis and mediates, in part, the enhancement of neurogenesis by dietary restriction in the hippocampus of adult mice. J. Neurochem. 2002, 82, 1367-1375. [CrossRef]

9. Bath, K.G.; Lee, F.S. Neurotrophic factor control of adult SVZ neurogenesis. Dev. Neurobiol. 2010, 70, 339-349. [CrossRef]

10. Lu, B.; Nagappan, G.; Lu, Y. BDNF and Synaptic Plasticity, Cognitive Function, and Dysfunction. In Neurotrophic Factors. Handbook of Experimental Pharmacology; Lewin, G., Carter, B., Eds.; Springer: Berlin/Heidelberg, Germany, 2014; pp. 223-250, ISBN 978-3-642-45105-8.

11. Zuccato, C.; Cattaneo, E. Brain-derived neurotrophic factor in neurodegenerative diseases. Nat. Rev. Neurol. 2009, 5, 311-322. [CrossRef]

12. Autry, A.E.; Monteggia, L.M. Brain-Derived Neurotrophic Factor and Neuropsychiatric Disorders. Pharmacol. Rev. 2012, 64, 238-258. [CrossRef] [PubMed]

13. Allen, S.J.; Watson, J.J.; Shoemark, D.K.; Barua, N.U.; Patel, N.K. GDNF, NGF and BDNF as therapeutic options for neurodegeneration. Pharmacol. Ther. 2013, 138, 155-175. [CrossRef] [PubMed]

14. Kowiański, P.; Lietzau, G.; Czuba, E.; Waśkow, M.; Steliga, A.; Moryś, J. BDNF: A Key Factor with Multipotent Impact on Brain Signaling and Synaptic Plasticity. Cell. Mol. Neurobiol. 2018, 38, 579-593. [CrossRef] [PubMed]

15. Aid, T.; Kazantseva, A.; Piirsoo, M.; Palm, K.; Timmusk, T. Mouse and ratBDNF gene structure and expression revisited. J. Neurosci. Res. 2007, 85, 525-535. [CrossRef] [PubMed]

16. Lu, J.-J.; Yang, M.; Sun, Y.; Zhou, X.-F. Synthesis, Trafficking and Release of BDNF. In Handbook of Neurotoxicity; Springer: New York, NY, USA, 2014; pp. 1955-1971.

17. Yang, J.; Siao, C.J.; Nagappan, G.; Marinic, T.; Jing, D.; McGrath, K.; Chen, Z.Y.; Mark, W.; Tessarollo, L.; Lee, F.S.; et al. Neuronal release of proBDNF. Nat. Neurosci. 2009, 12, 113-115. [CrossRef]

18. Rauskolb, S.; Zagrebelsky, M.; Dreznjak, A.; Deogracias, R.; Matsumoto, T.; Wiese, S.; Erne, B.; Sendtner, M.; Schaeren-Wiemers, N.; Korte, M.; et al. Global deprivation of brain-derived neurotrophic factor in the CNS reveals an area-specific requirement for dendritic growth. J. Neurosci. 2010, 30, 1739-1749. [CrossRef]

19. Yeh, C.-M.; Huang, C.-C.; Hsu, K.-S. Prenatal stress alters hippocampal synaptic plasticity in young rat offspring through preventing the proteolytic conversion of pro-brain-derived neurotrophic factor (BDNF) to mature BDNF. J. Physiol. 2012, 590, 991-1010. [CrossRef]

20. Je, H.S.; Yang, F.; Ji, Y.; Nagappan, G.; Hempstead, B.L.; Lu, B. Role of pro-brain-derived neurotrophic factor (proBDNF) to mature BDNF conversion in activity-dependent competition at developing neuromuscular synapses. Proc. Natl. Acad. Sci. USA 2012, 109, 15924-15929. [CrossRef] 
21. Castrén, E.; Antila, H. Neuronal plasticity and neurotrophic factors in drug responses. Mol. Psychiatry 2017, 22, 1085-1095. [CrossRef]

22. Mellios, N.; Huang, H.-S.; Grigorenko, A.; Rogaev, E.; Akbarian, S. A set of differentially expressed miRNAs, including miR-30a-5p, act as post-transcriptional inhibitors of BDNF in prefrontal cortex. Hum. Mol. Genet. 2008, 17, 3030-3042. [CrossRef]

23. Filipowicz, W.; Bhattacharyya, S.N.; Sonenberg, N. Mechanisms of post-transcriptional regulation by microRNAs: Are the answers in sight? Nat. Rev. Genet. 2008, 9, 102-114. [CrossRef] [PubMed]

24. Shi, J. Regulatory networks between neurotrophins and miRNAs in brain diseases and cancers. Acta Pharmacol. Sin. 2015, 36, 149-157. [CrossRef]

25. Caputo, V.; Sinibaldi, L.; Fiorentino, A.; Parisi, C.; Catalanotto, C.; Pasini, A.; Cogoni, C.; Pizzuti, A. Brain Derived Neurotrophic Factor (BDNF) Expression Is Regulated by MicroRNAs miR-26a and miR-26b Allele-Specific Binding. PLoS ONE 2011, 6, e28656. [CrossRef] [PubMed]

26. Tu, Z.; Li, Y.; Dai, Y.; Li, L.; Lv, G.; Chen, I.; Wang, B. MiR-140/BDNF axis regulates normal human astrocyte proliferation and LPS-induced IL-6 and TNF- $\alpha$ secretion. Biomed. Pharmacother. 2017, 91, 899-905. [CrossRef] [PubMed]

27. Zhang, K.; Wu, S.; Li, Z.; Zhou, J. MicroRNA-211/BDNF axis regulates LPS-induced proliferation of normal human astrocyte through PI3K/AKT pathway. Biosci. Rep. 2017, 37, BSR20170755. [CrossRef] [PubMed]

28. Thomas, K.T.; Gross, C.; Bassell, G.J. MicroRNAs Sculpt Neuronal Communication in a Tight Balance That Is Lost in Neurological Disease. Front. Mol. Neurosci. 2018, 11, 455. [CrossRef]

29. Li, Y.-J.; Xu, M.; Gao, Z.-H.; Wang, Y.-Q.; Yue, Z.; Zhang, Y.-X.; Li, X.-X.; Zhang, C.; Xie, S.-Y.; Wang, P.-Y. Alterations of Serum Levels of BDNF-Related miRNAs in Patients with Depression. PLoS ONE 2013, 8, e63648. [CrossRef]

30. Zheng, P.; Bin, H.; Chen, W. Inhibition of microRNA-103a inhibits the activation of astrocytes in hippocampus tissues and improves the pathological injury of neurons of epilepsy rats by regulating BDNF. Cancer Cell Int. 2019, 19, 109. [CrossRef]

31. Cagni, F.C.; das Campêlo, C.L.C.; Coimbra, D.G.; Barbosa, M.R.; Júnior, L.G.O.; Neto, A.B.S.; Ribeiro, A.M.; Júnior, C.O.G.; Gomes de Andrade, T.; Silva, R.H. Association of BDNF Val66MET Polymorphism With Parkinson's Disease and Depression and Anxiety Symptoms. J. Neuropsychiatry Clin. Neurosci. 2017, 29, 142-147. [CrossRef]

32. Lemos, J.R.; Alves, C.R.; de Souza, S.B.C.; Marsiglia, J.D.C.; Silva, M.S.M.; Pereira, A.C.; Teixeira, A.L.; Vieira, E.L.M.; Krieger, J.E.; Negrão, C.E.; et al. Peripheral vascular reactivity and serum BDNF responses to aerobic training are impaired by the BDNF Val66Met polymorphism. Physiol. Genom. 2016, 48, 116-123. [CrossRef]

33. Tsai, S.-J. Critical Issues in BDNF Val66Met Genetic Studies of Neuropsychiatric Disorders. Front. Mol. Neurosci. 2018, 11, 156. [CrossRef] [PubMed]

34. Kaplan, D.R.; Miller, F.D. Neurotrophin signal transduction in the nervous system. Curr. Opin. Neurobiol. 2000, 10, 381-391. [CrossRef]

35. Borodinova, A.A.; Salozhin, S.V. Differences in the Biological Functions of BDNF and proBDNF in the Central Nervous System. Neurosci. Behav. Physiol. 2017, 47, 251-265. [CrossRef]

36. Miranda, M.; Morici, J.F.; Zanoni, M.B.; Bekinschtein, P. Brain-Derived Neurotrophic Factor: A Key Molecule for Memory in the Healthy and the Pathological Brain. Front. Cell. Neurosci. 2019, 13, 363. [CrossRef] [PubMed]

37. Minichiello, L. TrkB signalling pathways in LTP and learning. Nat. Rev. Neurosci. 2009, 10, 850-860. [CrossRef]

38. Liu, X.; Obiany, O.; Chan, C.B.; Huang, J.; Xue, S.; Yang, J.J.; Zeng, F.; Goodman, M.; Ye, K. Biochemical and biophysical investigation of the brain-derived neurotrophic factor mimetic 7,8-dihydroxyflavone in the binding and activation of the trkb receptor. J. Biol. Chem. 2014, 289, 27571-27584. [CrossRef]

39. Reichardt, L.F. Neurotrophin-regulated signalling pathways. Philos. Trans. R. Soc. B Biol. Sci. 2006, 361, 1545-1564. [CrossRef]

40. Leal, G.; Bramham, C.R.; Duarte, C.B. BDNF and Hippocampal Synaptic Plasticity. Vitam. Horm. 2017, 104, 153-195.

41. Gorski, J.A.; Zeiler, S.R.; Tamowski, S.; Jones, K.R. Brain-derived neurotrophic factor is required for the maintenance of cortical dendrites. J. Neurosci. 2003, 23, 6856-6865. [CrossRef] [PubMed] 
42. Kwon, M.; Fernandez, J.R.; Zegarek, G.F.; Lo, S.B.; Firestein, B.L. BDNF-Promoted Increases in Proximal Dendrites Occur via CREB-Dependent Transcriptional Regulation of Cypin. J. Neurosci. 2011, 31, 9735-9745. [CrossRef]

43. Orefice, L.L.; Waterhouse, E.G.; Partridge, J.G.; Lalchandani, R.R.; Vicini, S.; Xu, B. Distinct Roles for Somatically and Dendritically Synthesized Brain-Derived Neurotrophic Factor in Morphogenesis of Dendritic Spines. J. Neurosci. 2013, 33, 11618-11632. [CrossRef] [PubMed]

44. Yoshii, A.; Constantine-Paton, M. Postsynaptic localization of PSD-95 is regulated by all three pathways downstream of TrkB signaling. Front. Synaptic Neurosci. 2014, 6, 6. [CrossRef] [PubMed]

45. Chen, T.; Wu, Y.; Wang, Y.; Zhu, J.; Chu, H.; Kong, L.; Yin, L.; Ma, H. Brain-Derived Neurotrophic Factor Increases Synaptic Protein Levels via the MAPK/Erk Signaling Pathway and Nrf2/Trx Axis Following the Transplantation of Neural Stem Cells in a Rat Model of Traumatic Brain Injury. Neurochem. Res. 2017, 42, 3073-3083. [CrossRef] [PubMed]

46. Opazo, P.; Watabe, A.M.; Grant, S.G.N.; O’Dell, T.J. Phosphatidylinositol 3-Kinase Regulates the Induction of Long-Term Potentiation through Extracellular Signal-Related Kinase-Independent Mechanisms. J. Neurosci. 2003, 23, 3679-3688. [CrossRef]

47. Kay, J.C.; Xia, C.-M.; Liu, M.; Shen, S.; Yu, S.J.; Chung, C.; Qiao, L.-Y. Endogenous PI3K/Akt and NMDAR act independently in the regulation of CREB activity in lumbosacral spinal cord in cystitis. Exp. Neurol. 2013, 250, 366-375. [CrossRef]

48. Petersén, Å.; Larsen, K.E.; Behr, G.G.; Romero, N.; Przedborski, S.; Brundin, P.; Sulzer, D. Brain-derived neurotrophic factor inhibits apoptosis and dopamine-induced free radical production in striatal neurons but does not prevent cell death. Brain Res. Bull. 2001, 56, 331-335. [CrossRef]

49. Patel, A.V.; Krimm, R.F. BDNF is required for the survival of differentiated geniculate ganglion neurons. Dev. Biol. 2010, 340, 419-429. [CrossRef]

50. Chen, A.; Xiong, L.-J.; Tong, Y.; Mao, M. Neuroprotective effect of brain-derived neurotrophic factor mediated by autophagy through the PI3K/Akt/mTOR pathway. Mol. Med. Rep. 2013, 8, 1011-1016. [CrossRef]

51. Wu, C.-H.; Chen, C.-C.; Hung, T.-H.; Chuang, Y.-C.; Chao, M.; Shyue, S.-K.; Chen, S.-F. Activation of TrkB/Akt signaling by a TrkB receptor agonist improves long-term histological and functional outcomes in experimental intracerebral hemorrhage. J. Biomed. Sci. 2019, 26, 53. [CrossRef]

52. Awad, B.I.; Carmody, M.A.; Steinmetz, M.P. Potential role of growth factors in the management of spinal cord injury. World Neurosurg. 2015, 83, 120-131. [CrossRef]

53. Sampaio, T.; Savall, A.; Gutierrez, M.Z.; Pinton, S. Neurotrophic factors in Alzheimer's and Parkinson's diseases: Implications for pathogenesis and therapy. Neural Regen. Res. 2017, 12, 549-557. [PubMed]

54. Pramanik, S.; Sulistio, Y.A.; Heese, K. Neurotrophin Signaling and Stem Cells-Implications for Neurodegenerative Diseases and Stem Cell Therapy. Mol. Neurobiol. 2017, 54, 7401-7459. [CrossRef]

55. Zoladz, J.A.; Pilc, A. The effect of physical activity on the brain derived neurotrophic factor: From animal to human studies. J. Physiol. Pharmacol. 2010, 61, 533-541. [PubMed]

56. Song, D.; Diao, J.; Yang, Y.; Chen, Y. MicroRNA-382 inhibits cell proliferation and invasion of retinoblastoma by targeting BDNF-mediated PI3K/AKT signalling pathway. Mol. Med. Rep. 2017, 16, 6428-6436. [CrossRef] [PubMed]

57. Yoo, J.-M.; Lee, B.D.; Sok, D.-E.; Ma, J.Y.; Kim, M.R. Neuroprotective action of N-acetyl serotonin in oxidative stress-induced apoptosis through the activation of both TrkB/CREB/BDNF pathway and Akt/Nrf2/Antioxidant enzyme in neuronal cells. Redox Biol. 2017, 11, 592-599. [CrossRef]

58. Porritt, M.J.; Batchelor, P.E.; Howells, D. Inhibiting BDNF expression by antisense oligonucleotide infusion causes loss of nigral dopaminergic neurons. Exp. Neurol. 2005, 192, 226-234. [CrossRef]

59. Scalzo, P.; Kümmer, A.; Bretas, T.L.; Cardoso, F.; Teixeira, A.L. Serum levels of brain-derived neurotrophic factor correlate with motor impairment in Parkinson's disease. J. Neurol. 2010, 257, 540-545. [CrossRef]

60. Grah, M.; Mihanovic, M.; Ruljancic, N.; Restek-Petrovic, B.; Molnar, S.; Jelavic, S. Brain-derived neurotrophic factor as a suicide factor in mental disorders. Acta Neuropsychiatr. 2014, 26, 356-363. [CrossRef]

61. Ventriglia, M.; Zanardini, R.; Bonomini, C.; Zanetti, O.; Volpe, D.; Pasqualetti, P.; Gennarelli, M.; Bocchio-Chiavetto, L. Serum Brain-Derived Neurotrophic Factor Levels in Different Neurological Diseases. Biomed Res. Int. 2013, 2013, 901082. [CrossRef] 
62. Howells, D.W.; Porritt, M.J.; Wong, J.Y.F.; Batchelor, P.E.; Kalnins, R.; Hughes, A.J.; Donnan, G.A. Reduced BDNF mRNA expression in the Parkinson's disease substantia nigra. Exp. Neurol. 2000, 166, 127-135. [CrossRef]

63. Lin, J.-G.; Chen, C.-J.; Yang, H.-B.; Chen, Y.-H.; Hung, S.-Y. Electroacupuncture Promotes Recovery of Motor Function and Reduces Dopaminergic Neuron Degeneration in Rodent Models of Parkinson's disease. Int. J. Mol. Sci. 2017, 18, 1846. [CrossRef] [PubMed]

64. Wang, Y.; Liu, H.; Zhang, B.-S.; Soares, J.C.; Zhang, X.Y. Low BDNF is associated with cognitive impairments in patients with Parkinson's disease. Parkinsonism Relat. Disord. 2016, 29, 66-71. [CrossRef]

65. Huang, Y.; Yun, W.; Zhang, M.; Luo, W.; Zhou, X. Serum concentration and clinical significance of brain-derived neurotrophic factor in patients with Parkinson's disease or essential tremor. J. Int. Med. Res. 2018, 46, 1477-1485. [CrossRef] [PubMed]

66. Siuda, J.; Patalong-Ogiewa, M.; Żmuda, W.; Targosz-Gajniak, M.; Niewiadomska, E.; Matuszek, I.; Jędrzejowska-Szypułka, H.; Rudzińska-Bar, M. Cognitive impairment and BDNF serum levels. Neurol. Neurochir. Pol. 2017, 51, 24-32. [CrossRef] [PubMed]

67. Leyhe, T.; Eschweiler, G.W.; Stransky, E.; Gasser, T.; Annas, P.; Basun, H.; Laske, C. Increase of BDNF Serum Concentration in Lithium Treated Patients with Early Alzheimer's Disease. J. Alzheimer's Dis. 2009, 16, 649-656. [CrossRef] [PubMed]

68. Song, J.-H.; Yu, J.-T.; Tan, L. Brain-Derived Neurotrophic Factor in Alzheimer's disease: Risk, Mechanisms, and Therapy. Mol. Neurobiol. 2015, 52, 1477-1493. [CrossRef]

69. Kang, S.S.; Zhang, Z.; Liu, X.; Manfredsson, F.P.; Benskey, M.J.; Cao, X.; Xu, J.; Sun, Y.E.; Ye, K. TrkB neurotrophic activities are blocked by $\alpha$-synuclein, triggering dopaminergic cell death in Parkinson's disease. Proc. Natl. Acad. Sci. USA 2017, 114, 10773-10778. [CrossRef]

70. Fang, F.; Yang, W.; Florio, J.B.; Rockenstein, E.; Spencer, B.; Orain, X.M.; Dong, S.X.; Li, H.; Chen, X.; Sung, K.; et al. Synuclein impairs trafficking and signaling of BDNF in a mouse model of Parkinson's disease. Sci. Rep. 2017, 7, 3868. [CrossRef]

71. Katila, N.; Bhurtel, S.; Shadfar, S.; Srivastav, S.; Neupane, S.; Ojha, U.; Jeong, G.-S.; Choi, D.-Y. Metformin lowers $\alpha$-synuclein phosphorylation and upregulates neurotrophic factor in the MPTP mouse model of Parkinson's disease. Neuropharmacology 2017, 125, 396-407. [CrossRef]

72. Baquet, Z.C.; Bickford, P.C.; Jones, K.R. Brain-Derived Neurotrophic Factor Is Required for the Establishment of the Proper Number of Dopaminergic Neurons in the Substantia Nigra Pars Compacta. J. Neurosci. 2005, 25, 6251-6259. [CrossRef]

73. Baydyuk, M.; Nguyen, M.T.; Xu, B. Chronic deprivation of TrkB signaling leads to selective late-onset nigrostriatal dopaminergic degeneration. Exp. Neurol. 2011, 228, 118-125. [CrossRef] [PubMed]

74. Ziebell, M.; Khalid, U.; Klein, A.B.; Aznar, S.; Thomsen, G.; Jensen, P.; Knudsen, G.M. Striatal dopamine transporter binding correlates with serum BDNF levels in patients with striatal dopaminergic neurodegeneration. Neurobiol. Aging 2012, 33, 428.e1-428.e5. [CrossRef] [PubMed]

75. Gerecke, K.M.; Jiao, Y.; Pani, A.; Pagala, V.; Smeyne, R.J. Exercise protects against MPTP-induced neurotoxicity in mice. Brain Res. 2010, 1341, 72-83. [CrossRef]

76. Baker, S.A.; Stanford, L.E.; Brown, R.E.; Hagg, T. Maturation but not survival of dopaminergic nigrostriatal neurons is affected in developing and aging BDNF-deficient mice. Brain Res. 2005, 1039, 177-188. [CrossRef] [PubMed]

77. Pałasz, E.; Bakk, A.; Gasiorowska, A.; Niewiadomska, G. The role of trophic factors and inflammatory processes in physical activity-induced neuroprotection in Parkinson's disease. Postepy Hig. Med. Doswiadczalnej (Online) 2017, 71, 713-726. [CrossRef] [PubMed]

78. Drinkut, A.; Tillack, K.; Meka, D.P.; Schulz, J.B.; Kügler, S.; Kramer, E.R. Ret is essential to mediate GDNF's neuroprotective and neuroregenerative effect in a Parkinson disease mouse model. Cell Death Dis. 2016, 7, e2359. [CrossRef]

79. Numakawa, T.; Suzuki, S.; Kumamaru, E.; Adachi, N.; Richards, M.; Kunugi, H. BDNF function and intracellular signaling in neurons. Histol. Histopathol. 2010, 25, 237-258. [PubMed]

80. Kaur, R.; Mehan, S.; Singh, S. Understanding multifactorial architecture of Parkinson's disease: Pathophysiology to management. Neurol. Sci. 2019, 40, 13-23. [CrossRef] [PubMed]

81. Andero, R.; Choi, D.C.; Ressler, K.J. BDNF-TrkB receptor regulation of distributed adult neural plasticity, memory formation, and psychiatric disorders. Prog. Mol. Biol. Transl. Sci. 2014, 122, 169-192. 
82. Park, H.; Kang, S.; Nam, E.; Suh, Y.-H.; Chang, K.-A. The Protective Effects of PSM-04 Against Beta Amyloid-Induced Neurotoxicity in Primary Cortical Neurons and an Animal Model of Alzheimer's Disease. Front. Pharmacol. 2019, 10, 2. [CrossRef]

83. Linnarsson, S.; Björklund, A.; Ernfors, P. Learning deficit in BDNF mutant mice. Eur. J. Neurosci. 1997, 9, 2581-2587. [CrossRef] [PubMed]

84. Du, X.; Iacovitti, L. Multiple signaling pathways direct the initiation of tyrosine hydroxylase gene expression in cultured brain neurons. Mol. Brain Res. 1997, 50, 1-8. [CrossRef]

85. Parain, K.; Murer, M.; Yan, Q.; Faucheux, B.; Agid, Y.; Hirsch, E.; Raisman-Vozari, R. Reduced expression of brain derived neurotrophic factor protein in Parkinson's disease substantia nigra. Neuroreport 1999, 10, 557-561. [CrossRef] [PubMed]

86. Guillin, O.; Diaz, J.; Carroll, P.; Griffon, N.; Schwartz, J.-C.; Sokoloff, P. BDNF controls dopamine D3 receptor expression and triggers behavioural sensitization. Nature 2001, 411, 86-89. [CrossRef]

87. Nagatsu, T.; Sawada, M. Biochemistry of postmortem brains in Parkinson's disease: Historical overview and future prospects. J. Neural Transm. Suppl. 2007, 72, 113-120.

88. Hung, H.C.; Lee, E.H.Y. The mesolimbic dopaminergic pathway is more resistant than the nigrostriatal dopaminergic pathway to MPTP and MPP+ toxicity: Role of BDNF gene expression. Mol. Brain Res. 1996, 41, 16-26. [CrossRef]

89. Tsukahara, T.; Takeda, M.; Shimohama, S.; Ohara, O.; Hashimoto, N. Effects of Brain-derived Neurotrophic Factor on 1-methyl-4-phenyl-1,2,3,6-tetrahydropyridine-induced Parkinsonism in Monkeys. Neurosurgery 1995, 37, 733-741. [CrossRef] [PubMed]

90. Klein, R.L.; Lewis, M.H.; Muzyczka, N.; Meyer, E.M. Prevention of 6-hydroxydopamine-induced rotational behavior by BDNF somatic gene transfer. Brain Res. 1999, 847, 314-320. [CrossRef]

91. Sun, M.; Kong, L.; Wang, X.; Lu, X.; Gao, Q.; Geller, A.I. Comparison of the capability of GDNF, BDNF, or both, to protect nigrostriatal neurons in a rat model of Parkinson's disease. Brain Res. 2005, 1052, 119-129. [CrossRef]

92. Kim, S.R.; Kareva, T.; Yarygina, O.; Kholodilov, N.; Burke, R.E. AAV transduction of dopamine neurons with constitutively active rheb protects from neurodegeneration and mediates axon regrowth. Mol. Ther. 2012, 20, 275-286. [CrossRef]

93. Nam, J.H.; Leem, E.; Jeon, M.T.; Jeong, K.H.; Park, J.W.; Jung, U.J.; Kholodilov, N.; Burke, R.E.; Jin, B.K.; Kim, S.R. Induction of GDNF and BDNF by hRheb(S16H) Transduction of SNpc Neurons: Neuroprotective Mechanisms of hRheb(S16H) in a Model of Parkinson's Disease. Mol. Neurobiol. 2015, 51, 487-499. [CrossRef]

94. Tronci, E.; Napolitano, F.; Muñoz, A.; Fidalgo, C.; Rossi, F.; Björklund, A.; Usiello, A.; Carta, M. BDNF over-expression induces striatal serotonin fiber sprouting and increases the susceptibility to L-DOPA-induced dyskinesia in 6-OHDA-lesioned rats. Exp. Neurol. 2017, 297, 73-81. [CrossRef] [PubMed]

95. Hernandez-Chan, N.G.; Bannon, M.J.; Orozco-Barrios, C.E.; Escobedo, L.; Zamudio, S.; De La Cruz, F.; Gongora-Alfaro, J.L.; Armendáriz-Borunda, J.; Reyes-Corona, D.; Espadas-Alvarez, A.J.; et al. Neurotensin-polyplex-mediated brain-derived neurotrophic factor gene delivery into nigral dopamine neurons prevents nigrostriatal degeneration in a rat model of early Parkinson's disease. J. Biomed. Sci. 2015, 22. [CrossRef] [PubMed]

96. Razgado-Hernandez, L.F.; Espadas-Alvarez, A.J.; Reyna-Velazquez, P.; Sierra-Sanchez, A.; Anaya-Martinez, V.; Jimenez-Estrada, I.; Bannon, M.J.; Martinez-Fong, D.; Aceves-Ruiz, J. The transfection of BDNF to dopamine neurons potentiates the effect of dopamine D3 receptor agonist recovering the striatal innervation, dendritic spines and motor behavior in an aged rat model of Parkinson's disease. PLoS ONE 2015, 10, e0117391. [CrossRef] [PubMed]

97. Lucidi-Phillipi, C.A.; Gage, F.H.; Shults, C.W.; Jones, K.R.; Reichardt, L.F.; Kang, U.J. Brain-derived neurotrophic factor-transduced fibroblasts: Production of BDNF and effects of grafting to the adult rat brain. J. Comp. Neurol. 1995, 354, 361-376. [CrossRef] [PubMed]

98. Yoshimoto, Y.; Lin, Q.; Collier, T.J.; Frim, D.M.; Breakefield, X.O.; Bohn, M.C. Astrocytes retrovirally transduced with BDNF elicit behavioral improvement in a rat model of Parkinson's disease. Brain Res. 1995, 691, 25-36. [CrossRef]

99. Frim, D.M.; Uhler, T.A.; Galpern, W.R.; Beal, M.F.; Breakefield, X.O.; Isacson, O. Implanted fibroblasts genetically engineered to produce brain-derived neurotrophic factor prevent 1-methyl-4-phenylpyridinium toxicity to dopaminergic neurons in the rat. Proc. Natl. Acad. Sci. USA 1994, 91, 5104-5108. [CrossRef] 
100. Galpern, W.R.; Frim, D.M.; Tatter, S.B.; Altar, C.A.; Beal, M.F.; Isacson, O. Cell-mediated delivery of brain-derived neurotrophic factor enhances dopamine levels in an MPP+ rat model of substantia nigra degeneration. Cell Transplant. 1996, 5, 225-232. [CrossRef]

101. Levivier, M.; Przedborski, S.; Bencsics, C.; Kang, U.J. Intrastriatal implantation of fibroblasts genetically engineered to produce brain-derived neurotrophic factor prevents degeneration of dopaminergic neurons in a rat model of Parkinson's disease. J. Neurosci. 1995, 15, 7810-7820. [CrossRef]

102. Zhu, G.; Li, J.; He, L.; Wang, X.; Hong, X. MPTP-induced changes in hippocampal synaptic plasticity and memory are prevented by memantine through the BDNF-TrkB pathway. Br. J. Pharmacol. 2015, 172, 2354-2368. [CrossRef]

103. Kinoshita, K.I.; Muroi, Y.; Unno, T.; Ishii, T. Rolipram improves facilitation of contextual fear extinction in the 1-methyl-4-phenyl-1,2,3,6-tetrahydropyridine-induced mouse model of Parkinson's disease. J. Pharmacol. Sci. 2017, 134, 55-58. [CrossRef] [PubMed]

104. Nagahara, A.H.; Tuszynski, M.H. Potential therapeutic uses of BDNF in neurological and psychiatric disorders. Nat. Rev. Drug Discov. 2011, 10, 209-219. [CrossRef] [PubMed]

105. Bradley, W.G. A controlled trial of recombinant methionyl human BDNF in ALS. Neurology 1999, 52, 1427-1433.

106. Ochs, G.; Penn, R.D.; York, M.; Giess, R.; Beck, M.; Tonn, J.; Haigh, J.; Malta, E.; Traub, M.; Sendtner, M.; et al. A phase I/II trial of recombinant methionyl human brain derived neurotrophic factor administered by intrathecal infusion to patients with amyotrophic lateral sclerosis. Amyotroph. Lateral Scler. Other Mot. Neuron Disord. 2000, 1, 201-206. [CrossRef]

107. Gill, S.S.; Patel, N.K.; Hotton, G.R.; O'Sullivan, K.; McCarter, R.; Bunnage, M.; Brooks, D.J.; Svendsen, C.N.; Heywood, P. Direct brain infusion of glial cell line-derived neurotrophic factor in Parkinson disease. Nat. Med. 2003, 9, 589-595. [CrossRef]

108. Slevin, J.T.; Gash, D.M.; Smith, C.D.; Gerhardt, G.A.; Kryscio, R.; Chebrolu, H.; Walton, A.; Wagner, R.; Young, A.B. Unilateral intraputamenal glial cell line-derived neurotrophic factor in patients with Parkinson disease: Response to 1 year of treatment and 1 year of withdrawal. J. Neurosurg. 2007, 106, 614-620. [CrossRef]

109. Kordower, J.H.; Palfi, S.; Chen, E.-Y.; Ma, S.Y.; Sendera, T.; Cochran, E.J.; Mufson, E.J.; Penn, R.; Goetz, C.G.; Comella, C.D. Clinicopathological findings following intraventricular glial-derived neurotrophic factor treatment in a patient with Parkinson's disease. Ann. Neurol. 1999, 46, 419-424. [CrossRef]

110. Whone, A.; Luz, M.; Boca, M.; Woolley, M.; Mooney, L.; Dharia, S.; Broadfoot, J.; Cronin, D.; Schroers, C.; Barua, N.U.; et al. Randomized trial of intermittent intraputamenal glial cell line-derived neurotrophic factor in Parkinson's disease. Brain 2019, 142, 512-525. [CrossRef]

111. Géral, C.; Angelova, A.; Lesieur, S. From Molecular to Nanotechnology Strategies for Delivery of Neurotrophins: Emphasis on Brain-Derived Neurotrophic Factor (BDNF). Pharmaceutics 2013, 5, $127-167$. [CrossRef]

112. Zhao, H.; Alam, A.; San, C.-Y.; Eguchi, S.; Chen, Q.; Lian, Q.; Ma, D. Molecular mechanisms of brain-derived neurotrophic factor in neuro-protection: Recent developments. Brain Res. 2017, 1665, 1-21. [CrossRef]

113. Denyer, R.; Douglas, M.R. Gene Therapy for Parkinson's disease. Parkinsons Dis. 2012, 2012, 1-13. [CrossRef] [PubMed]

114. Bunker, D.L.J. Delivery Techniques in Gene Therapy: A Brief Overview. J. Phys. Chem. Biophys. $2014,4$. [CrossRef]

115. Bjorklund, T.; Kordower, J.H. Gene therapy for Parkinson's disease. Mov. Disord. 2010, 25, S161-S173. [CrossRef] [PubMed]

116. Bemelmans, A.-P.; Horellou, P.; Pradier, L.; Brunet, I.; Colin, P.; Mallet, J. Brain-Derived Neurotrophic Factor-Mediated Protection of Striatal Neurons in an Excitotoxic Rat Model of Huntington's Disease, as Demonstrated by Adenoviral Gene Transfer. Hum. Gene Ther. 1999, 10, 2987-2997. [CrossRef] [PubMed]

117. Kells, A.P.; Fong, D.M.; Dragunow, M.; During, M.J.; Young, D.; Connor, B. AAV-Mediated gene delivery of BDNF or GDNF is neuroprotective in a model of huntington disease. Mol. Ther. 2004, 9, 682-688. [CrossRef] [PubMed] 
118. Paradiso, B.; Marconi, P.; Zucchini, S.; Berto, E.; Binaschi, A.; Bozac, A.; Buzzi, A.; Mazzuferi, M.; Magri, E.; Mora, G.N.; et al. Localized delivery of fibroblast growth factor-2 and brain-derived neurotrophic factor reduces spontaneous seizures in an epilepsy model. Proc. Natl. Acad. Sci. USA 2009, 106, 7191-7196. [CrossRef]

119. Nagahara, A.H.; Merrill, D.A.; Coppola, G.; Tsukada, S.; Schroeder, B.E.; Shaked, G.M.; Wang, L.; Blesch, A.; Kim, A.; Conner, J.M.; et al. Neuroprotective effects of brain-derived neurotrophic factor in rodent and primate models of Alzheimer's disease. Nat. Med. 2009, 15, 331-337. [CrossRef]

120. Majláth, Z.; Török, N.; Toldi, J.; Vécsei, L. Promising therapeutic agents for the treatment of Parkinson's disease. Expert Opin. Biol. Ther. 2016, 16, 787-799. [CrossRef]

121. Kirik, D.; Cederfjäll, E.; Halliday, G. Petersén Gene therapy for Parkinson's disease: Disease modification by GDNF family of ligands. Neurobiol. Dis. 2017, 97, 179-188. [CrossRef]

122. Valles, F.; Fiandaca, M.S.; Eberling, J.L.; Starr, P.A.; Larson, P.S.; Christine, C.W.; Forsayeth, J.; Richardson, R.M.; $\mathrm{Su}$, X.; Aminoff, M.J.; et al. Qualitative imaging of adeno-associated virus serotype 2-human aromatic L-amino acid decarboxylase gene therapy in a phase i study for the treatment of parkinson disease. Neurosurgery 2010, 67, 1377-1385. [CrossRef]

123. Marks, W.J.; Ostrem, J.L.; Verhagen, L.; Starr, P.A.; Larson, P.S.; Bakay, R.A.; Taylor, R.; Cahn-Weiner, D.A.; Stoessl, A.J.; Olanow, C.W.; et al. Safety and tolerability of intraputaminal delivery of CERE-120 (adeno-associated virus serotype 2-neurturin) to patients with idiopathic Parkinson's disease: An open-label, phase I trial. Lancet Neurol. 2008, 7, 400-408. [CrossRef]

124. Marks, W.J.; Bartus, R.T.; Siffert, J.; Davis, C.S.; Lozano, A.; Boulis, N.; Vitek, J.; Stacy, M.; Turner, D.; Verhagen, L.; et al. Gene delivery of AAV2-neurturin for Parkinson's disease: A double-blind, randomised, controlled trial. Lancet Neurol. 2010, 9, 1164-1172. [CrossRef]

125. Palasz, E.; Niewiadomski, W.; Gasiorowska, A.; Wysocka, A.; Stepniewska, A.; Niewiadomska, G. Exercise-Induced Neuroprotection and Recovery of Motor Function in Animal Models of Parkinson's Disease. Front. Neurol. 2019, 10, 1143. [CrossRef] [PubMed]

126. Lau, Y.-S.; Patki, G.; Das-Panja, K.; Le, W.-D.; Ahmad, S.O. Neuroprotective effects and mechanisms of exercise in a chronic mouse model of Parkinson's disease with moderate neurodegeneration. Eur. J. Neurosci. 2011, 33, 1264-1274. [CrossRef] [PubMed]

127. Tajiri, N.; Yasuhara, T.; Shingo, T.; Kondo, A.; Yuan, W.; Kadota, T.; Wang, F.; Baba, T.; Tayra, J.T.; Morimoto, T.; et al. Exercise exerts neuroprotective effects on Parkinson's disease model of rats. Brain Res. 2010, 1310, 200-207. [CrossRef] [PubMed]

128. Real, C.C.; Ferreira, A.F.B.; Chaves-Kirsten, G.P.; Torrão, A.S.; Pires, R.S.; Britto, L.R.G. BDNF receptor blockade hinders the beneficial effects of exercise in a rat model of Parkinson's disease. Neuroscience 2013, 237, 118-129. [CrossRef] [PubMed]

129. Wu, S.-Y.; Wang, T.-F.; Yu, L.; Jen, C.J.; Chuang, J.-I.; Wu, F.-S.; Wu, C.-W.; Kuo, Y.-M. Running exercise protects the substantia nigra dopaminergic neurons against inflammation-induced degeneration via the activation of BDNF signaling pathway. Brain Behav. Immun. 2011, 25, 135-146. [CrossRef] [PubMed]

130. Zhao, L.; He, L.X.; Huang, S.N.; Gong, L.J.; Li, L.; Lv, Y.Y.; Qian, Z.M. Protection of dopamine neurons by vibration training and up-regulation of brain-derived neurotrophic factor in a MPTP mouse model of Parkinson's disease. Physiol. Res. 2014, 63, 649-657. [PubMed]

131. Tuon, T.; Valvassori, S.S.; Dal Pont, G.C.; Paganini, C.S.; Pozzi, B.G.; Luciano, T.F.; Souza, P.S.; Quevedo, J.; Souza, C.T.; Pinho, R.A. Physical training prevents depressive symptoms and a decrease in brain-derived neurotrophic factor in Parkinson's disease. Brain Res. Bull. 2014, 108, 106-112. [CrossRef] [PubMed]

132. Fredriksson, A.; Stigsdotter, I.M.; Hurtig, A.; Ewalds-Kvist, B.; Archer, T. Running wheel activity restores MPTP-induced functional deficits. J. Neural Transm. 2011, 118, 407-420. [CrossRef]

133. Da Costa, R.O.; Gadelha-Filho, C.V.J.; da Costa, A.E.M.; Feitosa, M.L.; de Araújo, D.P.; de Lucena, J.D.; de Aquino, P.E.A.; Lima, F.A.V.; Neves, K.R.T.; de Barros Viana, G.S. The Treadmill Exercise Protects against Dopaminergic Neuron Loss and Brain Oxidative Stress in Parkinsonian Rats. Oxidative Med. Cell. Longev. 2017, 2017, 2138169. [CrossRef] [PubMed]

134. Choe, M.-A.; Koo, B.-S.; An, G.J.; Jeon, S. Effects of Treadmill Exercise on the Recovery of Dopaminergic Neuron Loss and Muscle Atrophy in the 6-OHDA Lesioned Parkinson's Disease Rat Model. Korean J. Physiol. Pharmacol. 2012, 16, 305-312. [CrossRef] 
135. Elsworth, J.D.; Roth, R.H. Dopamine synthesis, uptake, metabolism, and receptors: Relevance to gene therapy of Parkinson's disease. Exp. Neurol. 1997, 144, 4-9. [CrossRef] [PubMed]

136. Goldstein, D.S.; Holmes, C.; Bentho, O.; Sato, T.; Moak, J.; Sharabi, Y.; Imrich, R.; Conant, S.; Eldadah, B.A. Biomarkers to detect central dopamine deficiency and distinguish Parkinson disease from multiple system atrophy. Park. Relat. Disord. 2008, 14, 600-607. [CrossRef] [PubMed]

137. Ikeda, K.; Ebina, J.; Kawabe, K.; Iwasaki, Y. Dopamine transporter imaging in parkinson disease: Progressive changes and therapeutic modification after anti-parkinsonian medications. Intern. Med. 2019, 58, 1665-1672. [CrossRef]

138. Chen, G.; Bower, K.A.; Ma, C.; Fang, S.; Thiele, C.J.; Luo, J. Glycogen synthase kinase $3 \beta$ (GSK3 $\beta$ ) mediates 6-hydroxydopamine-induced neuronal death. FASEB J. 2004, 18, 1162-1164. [CrossRef] [PubMed]

139. Wang, W.; Yang, Y.; Ying, C.; Li, W.; Ruan, H.; Zhu, X.; You, Y.; Han, Y.; Chen, R.; Wang, Y.; et al. Inhibition of glycogen synthase kinase-3 $\beta$ protects dopaminergic neurons from MPTP toxicity. Neuropharmacology 2007, 52, 1678-1684. [CrossRef]

140. Xie, C.; Lin, J.-Y.; Wang, M.-H.; Zhang, Y.; Zhang, S.; Wang, X.-J.; Liu, Z.-G. Inhibition of Glycogen Synthase Kinase-3 $\beta$ (GSK-3 $\beta$ ) as potent therapeutic strategy to ameliorates L-dopa-induced dyskinesia in 6-OHDA parkinsonian rats. Sci. Rep. 2016, 6, 23527. [CrossRef]

141. Petit-Paitel, A.; Brau, F.; Cazareth, J.; Chabry, J. Involvment of Cytosolic and Mitochondrial GSK-3 $\beta$ in Mitochondrial Dysfunction and Neuronal Cell Death of MPTP/MPP ${ }^{+}$-Treated Neurons. PLoS ONE 2009, 4, e5491. [CrossRef]

142. Pérez-Sen, R.; Ortega, F.; Morente, V.; Delicado, E.G.; Miras-Portugal, M.T. P2X7, NMDA and BDNF receptors converge on GSK3 phosphorylation and cooperate to promote survival in cerebellar granule neurons. Cell. Mol. Life Sci. 2010, 67, 1723-1733.

143. Gerecke, K.M.; Jiao, Y.; Pagala, V.; Smeyne, R.J. Exercise Does Not Protect against MPTP-Induced Neurotoxicity in BDNF Happloinsufficent Mice. PLoS ONE 2012, 7, e43250. [CrossRef]

144. Paillard, T.; Rolland, Y.; de Souto Barreto, P. Protective Effects of Physical Exercise in Alzheimer's disease and Parkinson's disease: A Narrative Review. J. Clin. Neurol. 2015, 11, 212-219. [CrossRef]

145. Seifert, T.; Brassard, P.; Wissenberg, M.; Rasmussen, P.; Nordby, P.; Stallknecht, B.; Adser, H.; Jakobsen, A.H.; Pilegaard, H.; Nielsen, H.B.; et al. Endurance training enhances BDNF release from the human brain. Am. J. Physiol. Regul. Integr. Comp. Physiol. 2010, 298, R372-R377. [CrossRef]

146. Conradsson, D.; Löfgren, N.; Nero, H.; Hagströmer, M.; Ståhle, A.; Lökk, J.; Franzén, E. The Effects of Highly Challenging Balance Training in Elderly with Parkinson's disease: A Randomized Controlled Trial. Neurorehabilit. Neural Repair 2015, 29, 827-836. [CrossRef]

147. Uhrbrand, A.; Stenager, E.; Pedersen, M.S.; Dalgas, U. Parkinson's disease and intensive exercise therapy-A systematic review and meta-analysis of randomized controlled trials. J. Neurol. Sci. 2015, 353, 9-19. [CrossRef]

148. Lamotte, G.; Rafferty, M.R.; Prodoehl, J.; Kohrt, W.M.; Comella, C.L.; Simuni, T.; Corcos, D.M. Effects of Endurance Exercise Training on The Motor and Non-Motor Features of Parkinson's Disease: A Review. J. Parkinsons Dis. 2015, 5, 21-41. [CrossRef] [PubMed]

149. Santos, S.M.; da Silva, R.A.; Terra, M.B.; Almeida, I.A.; de Melo, L.B.; Ferraz, H.B. Balance versus resistance training on postural control in patients with Parkinson's disease: A randomized controlled trial. Eur. J. Phys. Rehabil. Med. 2017, 53, 173-183. [PubMed]

150. O'Callaghan, A.; Harvey, M.; Houghton, D.; Gray, W.K.; Weston, K.L.; Oates, L.L.; Romano, B.; Walker, R.W. Comparing the influence of exercise intensity on brain-derived neurotrophic factor serum levels in people with Parkinson's disease: A pilot study. Aging Clin. Exp. Res. 2019. [CrossRef] [PubMed]

151. Fernandes, B.; Barbieri, F.A.; Arthuso, F.Z.; Silva, F.A.; Moretto, G.F.; Imaizumi, L.F.I.; Ngomane, A.Y.; Guimarães, G.V.; Ciolac, E.G. High-Intensity Interval Versus Moderate-Intensity Continuous Training in Individuals With Parkinson's Disease: Hemodynamic and Functional Adaptation. J. Phys. Act. Health 2019, 1-7. [CrossRef] [PubMed]

152. Fiorelli, C.M.; Ciolac, E.G.; Simieli, L.; Silva, F.A.; Fernandes, B.; Christofoletti, G.; Barbieri, F.A. Differential Acute Effect of High-Intensity Interval or Continuous Moderate Exercise on Cognition in Individuals With Parkinson's Disease. J. Phys. Act. Health 2019, 16, 157-164. [CrossRef] 
153. Marusiak, J.; Zeligowska, E.; Mencel, J.; Kisiel-Sajewicz, K.; Majerczak, J.; Zoladz, J.A.; Jaskólski, A.; Jaskólska, A. Interval training-induced alleviation of rigidity and hypertonia in patients with Parkinson's disease is accompanied by increased basal serum brain-derived neurotrophic factor: A repeated-measures, case series pilot study. J. Rehabil. Med. 2015, 47, 372-375. [CrossRef]

154. Santana-Sosa, E.; Barriopedro, M.; López-Mojares, L.; Pérez, M.; Lucia, A. Exercise Training is Beneficial for Alzheimer's Patients. Int. J. Sports Med. 2008, 29, 845-850. [CrossRef] [PubMed]

155. Brienesse, L.A.; Emerson, M.N. Effects of Resistance Training for People with Parkinson's disease: A Systematic Review. J. Am. Med. Dir. Assoc. 2013, 14, 236-241. [CrossRef] [PubMed]

156. Bressel, E.; Wing, J.E.; Miller, A.I.; Dolny, D.G. High-Intensity Interval Training on an Aquatic Treadmill in Adults with Osteoarthritis. J. Strength Cond. Res. 2014, 28, 2088-2096. [CrossRef] [PubMed]

157. Skriver, K.; Roig, M.; Lundbye-Jensen, J.; Pingel, J.; Helge, J.W.; Kiens, B.; Nielsen, J.B. Acute exercise improves motor memory: Exploring potential biomarkers. Neurobiol. Learn. Mem. 2014, 116, 46-58. [CrossRef] [PubMed]

158. Filus, J.; Rybakowski, J. Serum BDNF levels and intensity of depressive symptoms. Neuropsychiatr. Neuropsychol. 2010, 5, 155-162.

159. Piotrowicz, Z.; Czuba, M.; Langfort, J.; Chalimoniuk, M. Alterations in serum BDNF and catecholamines during exercise to volitional exhaustion-The influence of normobaric hypoxia and endurance training. Folia Neuropathol. 2017, 55, 173.

160. Knaepen, K.; Goekint, M.; Heyman, E.M.; Meeusen, R. Neuroplasticity-Exercise-Induced Response of Peripheral Brain-Derived Neurotrophic Factor. Sports Med. 2010, 40, 765-801. [CrossRef]

161. Sakuma, K.; Yamaguchi, A. The Recent Understanding of the Neurotrophin's Role in Skeletal Muscle Adaptation. J. Biomed. Biotechnol. 2011, 2011, 201696. [CrossRef]

162. Ahlskog, J.E. Does vigorous exercise have a neuroprotective effect in Parkinson disease? Neurology 2011, 77, 288-294. [CrossRef]

163. Liu, P.Z.; Nusslock, R. Exercise-Mediated Neurogenesis in the Hippocampus via BDNF. Front. Neurosci. 2018, 12, 52. [CrossRef] [PubMed]

164. Schmolesky, M.T.; Webb, D.L.; Hansen, R.A. The effects of aerobic exercise intensity and duration on levels of brain-derived neurotrophic factor in healthy men. J. Sports Sci. Med. 2013, 12, 502-511. [PubMed]

165. Zhang, J.; Sokal, I.; Peskind, E.R.; Quinn, J.F.; Jankovic, J.; Kenney, C.; Chung, K.A.; Millard, S.P.; Nutt, J.G.; Montine, T.J. CSF Multianalyte Profile Distinguishes Alzheimer and Parkinson Diseases. Am. J. Clin. Pathol. 2008, 129, 526-529. [CrossRef]

166. Salehi, Z.; Mashayekhi, F. Brain-derived neurotrophic factor concentrations in the cerebrospinal fluid of patients with Parkinson's disease. J. Clin. Neurosci. 2009, 16, 90-93. [CrossRef]

167. Hirsch, M.A.; van Wegen, E.E.H.; Newman, M.A.; Heyn, P.C. Exercise-induced increase in brain-derived neurotrophic factor in human Parkinson's disease: A systematic review and meta-analysis. Transl. Neurodegener. 2018, 7. [CrossRef]

168. Matthews, V.B.; Åström, M.-B.; Chan, M.H.S.; Bruce, C.R.; Krabbe, K.S.; Prelovsek, O.; Åkerström, T.; Yfanti, C.; Broholm, C.; Mortensen, O.H.; et al. Brain-derived neurotrophic factor is produced by skeletal muscle cells in response to contraction and enhances fat oxidation via activation of AMP-activated protein kinase. Diabetologia 2009, 52, 1409-1418. [CrossRef]

169. Pratesi, A. Skeletal muscle: An endocrine organ. Clin. Cases Miner. Bone Metab. 2013, 10, 11-14. [CrossRef]

170. Zhang, Z.; Wang, B.; Fei, A. BDNF contributes to the skeletal muscle anti-atrophic effect of exercise training through AMPK-PGC1 $\alpha$ signaling in heart failure mice. Arch. Med. Sci. 2019, 15, 214-222. [CrossRef]

171. Pareja-Galeano, H.; Alis, R.; Sanchis-Gomar, F.; Cabo, H.; Cortell-Ballester, J.; Gomez-Cabrera, M.C.; Lucia, A.; Viña, J. Methodological considerations to determine the effect of exercise on brain-derived neurotrophic factor levels. Clin. Biochem. 2015, 48, 162-166. [CrossRef]

172. Kallies, G.; Rapp, M.A.; Fydrich, T.; Fehm, L.; Tschorn, M.; Terán, C.; Schwefel, M.; Pietrek, A.; Henze, R.; Hellweg, R.; et al. Serum brain-derived neurotrophic factor (BDNF) at rest and after acute aerobic exercise in major depressive disorder. Psychoneuroendocrinology 2019, 102, 212-215. [CrossRef]

173. Walsh, J.J.; Tschakovsky, M.E. Exercise and circulating BDNF: Mechanisms of release and implications for the design of exercise interventions. Appl. Physiol. Nutr. Metab. 2018, 43, 1095-1104. [CrossRef] [PubMed] 
174. Rasmussen, P.; Brassard, P.; Adser, H.; Pedersen, M.V.; Leick, L.; Hart, E.; Secher, N.H.; Pedersen, B.K.; Pilegaard, H. Evidence for a release of brain-derived neurotrophic factor from the brain during exercise. Exp. Physiol. 2009, 94, 1062-1069. [CrossRef] [PubMed]

175. Klein, A.B.; Williamson, R.; Santini, M.A.; Clemmensen, C.; Ettrup, A.; Rios, M.; Knudsen, G.M.; Aznar, S. Blood BDNF concentrations reflect brain-tissue BDNF levels across species. Int. J. Neuropsychopharmacol. 2011, 14, 347-353. [CrossRef] [PubMed]

176. Gustafsson, G.; Lira, C.M.; Johansson, J.; Wisén, A.; Wohlfart, B.; Ekman, R.; Westrin, Å. The acute response of plasma brain-derived neurotrophic factor as a result of exercise in major depressive disorder. Psychiatry Res. 2009, 169, 244-248. [CrossRef] [PubMed]

177. Rojas Vega, S.; Strüder, H.K.; Vera Wahrmann, B.; Schmidt, A.; Bloch, W.; Hollmann, W. Acute BDNF and cortisol response to low intensity exercise and following ramp incremental exercise to exhaustion in humans. Brain Res. 2006, 1121, 59-65. [CrossRef] [PubMed]

178. Zoladz, J.A.; Majerczak, J.; Zeligowska, E.; Mencel, J.; Jaskolski, A.; Jaskolska, A.; Marusiak, J. Moderate-intensity interval training increases serum brain-derived neurotrophic factor level and decreases inflammation in Parkinson's disease patients. J. Physiol. Pharmacol. 2014, 65, 441-448.

179. Palasz, E.; Niewiadomski, W.; Gasiorowska, A.; Mietelska-Porowska, A.; Niewiadomska, G. Neuroplasticity and Neuroprotective Effect of Treadmill Training in the Chronic Mouse Model of Parkinson's Disease. Neural Plast. 2019, 2019, 8215017. [CrossRef]

180. Fontanesi, C.; Kvint, S.; Frazzitta, G.; Bera, R.; Ferrazzoli, D.; Di Rocco, A.; Rebholz, H.; Friedman, E.; Pezzoli, G.; Quartarone, A.; et al. Intensive Rehabilitation Enhances Lymphocyte BDNF-TrkB Signaling in Patients With Parkinson's Disease. Neurorehabilit. Neural Repair 2016, 30, 411-418. [CrossRef]

181. Da Silva, P.G.C.; Domingues, D.D.; De Carvalho, L.A.; Allodi, S.; Correa, C.L. Neurotrophic factors in Parkinson's disease are regulated by exercise: Evidence-based practice. J. Neurol. Sci. 2016, 363, 5-15. [CrossRef]

182. Gómez-Pinilla, F.; Ying, Z.; Opazo, P.; Roy, R.R.; Edgerton, V.R. Differential regulation by exercise of BDNF and NT-3 in rat spinal cord and skeletal muscle. Eur. J. Neurosci. 2001, 13, 1078-1084. [CrossRef]

183. Fahimi, A.; Baktir, M.A.; Moghadam, S.; Mojabi, F.S.; Sumanth, K.; McNerney, M.W.; Ponnusamy, R.; Salehi, A. Physical exercise induces structural alterations in the hippocampal astrocytes: Exploring the role of BDNF-TrkB signaling. Brain Struct. Funct. 2017, 222, 1797-1808. [CrossRef] [PubMed]

184. Cho, H.-S.; Shin, M.-S.; Song, W.; Jun, T.-W.; Lim, B.-V.; Kim, Y.-P.; Kim, C.-J. Treadmill exercise alleviates short-term memory impairment in 6-hydroxydopamine-induced Parkinson's rats. J. Exerc. Rehabil. 2013, 9 , 354-361. [CrossRef] [PubMed]

185. Sung, Y.-H. Effects of treadmill exercise on hippocampal neurogenesis in an MPTP/probenecid-induced Parkinson's disease mouse model. J. Phys. Ther. Sci. 2015, 27, 3203-3206. [CrossRef]

186. Zheng, W.-H.; Quirion, R. Comparative signaling pathways of insulin-like growth factor-1 and brain-derived neurotrophic factor in hippocampal neurons and the role of the PI3 kinase pathway in cell survival. J. Neurochem. 2004, 89, 844-852. [CrossRef] [PubMed]

187. Wrann, C.D.; White, J.P.; Salogiannnis, J.; Laznik-Bogoslavski, D.; Wu, J.; Ma, D.; Lin, J.D.; Greenberg, M.E.; Spiegelman, B.M. Exercise Induces Hippocampal BDNF through a PGC-1 $\alpha /$ FNDC5 Pathway. Cell Metab. 2013, 18, 649-659. [CrossRef]

188. Jodeiri Farshbaf, M.; Ghaedi, K.; Megraw, T.L.; Curtiss, J.; Shirani Faradonbeh, M.; Vaziri, P.; Nasr-Esfahani, M.H. Does PGC1 $\alpha /$ FNDC5/BDNF Elicit the Beneficial Effects of Exercise on Neurodegenerative Disorders? Neuromol. Med. 2016, 18, 1-15. [CrossRef]

189. Pyrzak, B.; Demkow, U.; Kucharska, A.M. Brown Adipose Tissue and Browning Agents: Irisin and FGF21 in the Development of Obesity in Children and Adolescents. Adv. Exp. Med. Biol. 2015, 866, $25-34$.

190. Natalicchio, A.; Marrano, N.; Biondi, G.; Dipaola, L.; Spagnuolo, R.; Cignarelli, A.; Perrini, S.; Laviola, L.; Giorgino, F. Irisin Increases the Expression of Anorexigenic and Neurotrophic Genes in Mouse Brain. Diabetes Metab. Res. Rev. 2019, 19, e3238. [CrossRef]

191. Guo, Z.; Du, X.; Iacovitti, L. Regulation of tyrosine hydroxylase gene expression during transdifferentiation of striatal neurons: Changes in transcription factors binding the AP-1 site. J. Neurosci. 1998, 18, 8163-8174. [CrossRef] 
192. Nagamoto-Combs, K.; Piech, K.M.; Best, J.A.; Sun, B.; Tank, A.W. Tyrosine Hydroxylase Gene Promoter Activity Is Regulated by Both Cyclic AMP-responsive Element and AP1 Sites following Calcium Influx. J. Biol. Chem. 1997, 272, 6051-6058. [CrossRef]

193. He, X.; Yang, S.; Zhang, R.; Hou, L.; Xu, J.; Hu, Y.; Xu, R.; Wang, H.; Zhang, Y. Smilagenin Protects Dopaminergic Neurons in Chronic MPTP/Probenecid—Lesioned Parkinson's Disease Models. Front. Cell. Neurosci. 2019, 13, 18. [CrossRef] [PubMed]

194. Rangasamy, S.B.; Dasarathi, S.; Pahan, P.; Jana, M.; Pahan, K. Low-Dose Aspirin Upregulates Tyrosine Hydroxylase and Increases Dopamine Production in Dopaminergic Neurons: Implications for Parkinson's disease. J. Neuroimmune Pharmacol. 2019, 14, 173-187. [CrossRef] [PubMed]

195. Vaynman, S.; Ying, Z.; Gomez-Pinilla, F. Interplay between brain-derived neurotrophic factor and signal transduction modulators in the regulation of the effects of exercise on synaptic-plasticity. Neuroscience 2003, 122, 647-657. [CrossRef] [PubMed]

196. Rabie, M.A.; Abd El Fattah, M.A.; Nassar, N.N.; El-Abhar, H.S.; Abdallah, D.M. Angiotensin 1-7 ameliorates 6-hydroxydopamine lesions in hemiparkinsonian rats through activation of MAS receptor/PI3K/Akt/BDNF pathway and inhibition of angiotensin II type-1 receptor/NF-kB axis. Biochem. Pharmacol. 2018, 151, 126-134. [CrossRef] [PubMed]

197. McMorris, T.; Collard, K.; Corbett, J.; Dicks, M.; Swain, J.P. A test of the catecholamines hypothesis for an acute exercise-cognition interaction. Pharmacol. Biochem. Behav. 2008, 89, 106-115. [CrossRef] [PubMed]

198. McMorris, T. Developing the catecholamines hypothesis for the acute exercise-cognition interaction in humans: Lessons from animal studies. Physiol. Behav. 2016, 165, 291-299. [CrossRef]

199. Ma, Q. Beneficial effects of moderate voluntary physical exercise and its biological mechanisms on brain health. Neurosci. Bull. 2008, 24, 265-270. [CrossRef]

200. Lopez-Alvarez, V.M.; Puigdomenech, M.; Navarro, X.; Cobianchi, S. Monoaminergic descending pathways contribute to modulation of neuropathic pain by increasing-intensity treadmill exercise after peripheral nerve injury. Exp. Neurol. 2018, 299, 42-55. [CrossRef]

201. Huat, T.J.; Khan, A.A.; Pati, S.; Mustafa, Z.; Abdullah, J.M.; Jaafar, H. IGF-1 enhances cell proliferation and survival during early differentiation of mesenchymal stem cells to neural progenitor-like cells. BMC Neurosci. 2014, 15. [CrossRef]

202. Maass, A.; Düzel, S.; Brigadski, T.; Goerke, M.; Becke, A.; Sobieray, U.; Neumann, K.; Lövdén, M.; Lindenberger, U.; Bäckman, L.; et al. Relationships of peripheral IGF-1, VEGF and BDNF levels to exercise-related changes in memory, hippocampal perfusion and volumes in older adults. Neuroimage 2016, 131, 142-154. [CrossRef]

203. Cobianchi, S.; Arbat-Plana, A.; Lopez-Alvarez, V.M.; Navarro, X. Neuroprotective Effects of Exercise Treatments after Injury: The Dual Role of Neurotrophic Factors. Curr. Neuropharmacol. 2017, 15, 495-518. [CrossRef] [PubMed]

204. Yuskaitis, C.J.; Jope, R.S. Glycogen synthase kinase-3 regulates microglial migration, inflammation, and inflammation-induced neurotoxicity. Cell. Signal. 2009, 21, 264-273. [CrossRef]

205. Green, H.F.; Nolan, Y.M. GSK-3 mediates the release of IL-1 $\beta$, TNF- $\alpha$ and IL-10 from cortical glia. Neurochem. Int. 2012, 61, 666-671. [CrossRef] [PubMed]

206. Yang, J.; Ru, J.; Ma, W.; Gao, Y.; Liang, Z.; Liu, J.; Guo, J.; Li, L. BDNF promotes the growth of human neurons through crosstalk with the Wnt/ $\beta$-catenin signaling pathway via GSK-3 $\beta$. Neuropeptides 2015, 54, $35-46$. [CrossRef] [PubMed]

(C) 2020 by the authors. Licensee MDPI, Basel, Switzerland. This article is an open access article distributed under the terms and conditions of the Creative Commons Attribution (CC BY) license (http://creativecommons.org/licenses/by/4.0/). 